\title{
Adding Molecules to Food, Pros and Cons - A Review on Synthetic and Natural Food Additives
}

\author{
MÁRCIO CAROCHO ${ }^{\mathrm{a}, \mathrm{b}}$, MARIA FILOMENA BARREIRO ${ }^{\mathrm{c}}$, PATRICIA MORALES ${ }^{\mathrm{b}, *}$ and \\ ISABEL C.F.R. FERREIRA ${ }^{\mathrm{a}, *}$ \\ ${ }^{a}$ Mountain Research Center (CIMO) ESA, Polytechnic Institute of Bragança, Campus de Santa Apolónia, \\ Apartado 1172, 5301-855, Bragança, Portugal \\ ${ }^{\mathrm{b}}$ Department of Nutrition and Bromatology II, Faculty of Pharmacy, Complutense University of Madrid, \\ Pza Ramón y Cajal, s/n, E-28040 Madrid, Spain \\ ${ }^{\mathrm{c}}$ Laboratory of Separation and Reaction Engineering (LSRE), Associate Laboratory LSRE/LCM, \\ Polytechnic Institute of Bragança, Campus Santa Apolónia Apartado 1134, 5301-857 Bragança, Portugal \\ *Corresponding authors: patricia.morales@farm.ucm.es (Tel: (34)913941802); iferreira@ipb.pt
} (Tel:(351)273303219 Fax: (351)273325405))

\section{ABSTRACT}

The pressing issue to feed the increasing world population has created a demand to enhance food production, which has to be cheaper, but at the same time must meet high quality standards. Taste, appearance, texture, and microbiological safety are required to be preserved within a foodstuff for the longest period of time. Although considerable improvements have been achieved in terms of food additives, some are still enveloped in controversy. The lack of uniformity in worldwide laws regarding additives, along with conflicting results of many studies help foster this controversy. In this report the most important preservatives, nutritional additives, coloring, flavoring, texturizing, and miscellaneous agents are analyzed in terms of safety and toxicity. Natural additives and extracts, which are gaining interest due to changes in consumer habits are also evaluated in terms of their benefits to health and combined effects. Technologies, like edible coatings and films which have helped overcome some drawbacks of additives, but still pose some disadvantages, are briefly addressed. 
Future trends like nanoencapsulation and the development of "smart" additives and packages, specific vaccines for intolerance to additives, use of fungi to produce additives, and DNA recombinant technologies are summarized.

Keywords: Natural food additives; Antimicrobial; Antioxidant; Conservatives; Colorants

\section{HISTORIC BACKGROUND OF FOOD ADDITIVES}

Since the dawn of man, our species searches for better ways to feed itself, by developing more efficient methods of hunting, animal/vegetable domestication, food preservation by physical methods, and finally, by adding molecules to food in order to enhance flavors or to preserve it.

Back in the 1800's food additives were intentionally used for food adulteration. This practice was widespread due to the centralization of food processing, decline of personal accountability, birth of analytical chemistry and inadequate governmental regulation. The consequence of such uncontrolled tampering of food led to a serious worldwide problem with concern about food quality rising gradually. In 1920, the availability of effective methods for food analysis, together with regulatory pressures, started to reduce the significance of this problem. In the middle of the $20^{\text {th }}$ century, processed food became an important part of human nutrition, and legal chemical additives became increasingly prevalent in them, fostering tight regulation, which still remains controversial due to the high number of studies concerning food additives that produce conflicting results and different interpretations by governments (Fennema 1987). 
Today, more than 2500 additives are intentionally added to food in order to keep certain properties or to extend shelf-life, while many others were banned throughout the years, some of them at a global level and others only in specific countries (Branen and others 2001). The definition of food additive has changed during time, being today defined as "any substance not normally consumed as a food by itself and not normally used as a typical ingredient of the food, whether or not it has nutritive value, the intentional addition of which to food for a technological (including organoleptic) purpose in the manufacture, processing, preparation, treatment, packing, packaging, transport or holding of such food results, or may be reasonably expected to result (directly or indirectly), in it or its by-products becoming a component of or otherwise affecting the characteristics of such foods. The term does not include contaminants or substances added to food for maintaining or improving nutritional qualities" (Codex Alimentarius). This definition was proposed in 1995 by the joint panel, comprised by the Food and Agriculture Organization of the United Nations (FAO) and by the World Health Organization (WHO) and being revised during all the subsequent years, with the last revision in 2012. Today, the Codex Alimentarius gathers all the information regarding standards, codes of practice and guidelines about food and its processing. Worldwide, the 2 major regulators of food additives are the European Food Safety Authority (EFSA) and the Food and Drug Administration (FDA) of the United States of America.

\section{FOOD ADDITIVES IN THE XXI CENTURY}

Today, mankind depends on food additives; in fact, the industrialized world would not have been possible without them. The citizens of industrialized societies are not often involved in the cultivation, harvesting, and processing of the food they eat. Due to this 
fact, processed food has to be transported across large distances to reach consumers. In order to ensure that the food reaches its destination in good conditions, special requirements are needed, mainly to prevent contamination and spoilage (Cheng and others 2010; Lerner and Lerner 2011; Becerril and others 2013). These requirements involve the correct packaging and environmental conditions, as well as the incorporation of additives to preserve or enhance different parameters. Although research concerning food additives (Patel and others 2010; Maqsood and others 2013), their impact on health and behavior (Gultekin and others 2013; Martyn and others 2013), as well as the methods to detect them (González and others 1999; Ferreira and others 2000; Frazier and others 2000; Watson 2002; Saad and others 2005; Isaac and others 2006; Wang and others 2006; García-Jiménez and Capitán-Vallvey 2007; Yoshioka and Ichihashi 2008; Cantarelli and others 2009; Chen and Ni 2009; Xiu-Qin and others 2009; Merusi and others 2010; Yoshikawa and others 2011; Ohtsuki and others 2012; Pundir and Rawal 2013) is growing exponentially, much speculation, inconsistencies, controversy, and health risks still remain unclear and are object of ample debate. Adding to this fact is the growing pressure to produce new and more effective additives pushing the regulations to become tighter to detect adulterations and excessive use of certain additives as fast as possible.

In 2001, the Centers for Disease Control and Prevention (CDC) of the United States of America estimated that there were about 76 million cases of food-borne illnesses in the US alone, each year, resulting in about 5000 deaths. The associated cost of food-borne illnesses with specific strains of bacteria is estimated to be between 6.5 to 34.9 billion dollars. For the same year, in England and Wales 100000 cases were reported, and authorities believe this number was not accurate, since many of the occurrences were not reported (Cleveland and others 2001; Smith-Palmer and others 2001). 
The FDA has been blamed by the Council for Responsible Nutrition (CRN) for creating a very strict and unachievable draft guidance in order to approve new dietary ingredients, comparing their approval to those of food additives, which are tested to a higher threshold than the reasonable expectation of safety prescribed by the Congress (Mister and Hathcock 2012). In 2011 the FDA's exposure assessment approaches were reviewed, and it was concluded that the agency should develop a science-based framework to prioritize and reassess prior safety decisions, and conduct more extensive postmarket monitoring while communicating and exchanging scientific information with stakeholders (Alger and others 2013). The EFSA also gathered a scientific forum in 2008 to join scientists around food safety issues in Europe. The authority revealed that consumer confidence was growing since its foundation in 2002, a year in which it was low due to the 1990's food-related issues. In that forum, food additives were considered desirable due to the function they carried out, but could, in some cases, have negative effects on health (Bronzwaer 2008). Since 2010, both the European Commission Regulation along with EFSA have started a program to re-evaluate all the existing approved food additives. The first evaluation includes food colorants and preservatives (including antimicrobials and antioxidants), which has to be concluded before 2015. The second group to be evaluated, comprising texturizing agents (including emulsifiers, stabilizers, and gelling agents) by 2018, and the last group, sweeteners, to be revised until 2020 (Lodi and others 2011). This re-evaluation of food additives brings an opportunity to pursue research towards the use of natural additives, while clarifying doubts that still might persist in food producing companies, the scientific community, among stakeholders, regulating bodies and consumers.

In the European Union (EU), all food additives, whether approved or not in the EU, are labeled with the letter "E" (representing Europe) and a specific number. This 
nomenclature was extended to the Codex Alimentarius Commission to easily identify food additives worldwide. A huge effort was put in motion to gather knowledge towards the creation of a single database of legal additives to be used within the EU, and in the Regulation 1129, of 2011, all the approved additives as well as their Acceptable Daily Intake (ADI) were listed (Council Regulation (EC) 1333/2008; Council Regulation (EC) 1129/2011). In the USA, as from 1961, the FDA determined that all food components were labeled as Generally Regarded as Safe (GRAS). This term is still in use today, but for an additive to be considered in it, various toxicology assays must be performed, and the list has seen changes throughout the years. The FDA, although quite resistant to approve new food additives has an online database covering "Everything Added to Food in the United States" (EAFUS) were all the compounds added to food, including additives, are compiled, as well as the FDA Redbook with guides and legislation for the food industry (Branen and others 2001; FDA EAFUS; FDA Redbook)

The highest dose at which no adverse effects are observed in the most susceptible animal species is identified as the No Observed Adverse Effect Level (NOAEL). This parameter is used as the basis for setting the human safety standards for food additives. NOAEL is measured in milligrams per kilogram of body weight per day. The Acceptable Daily Intake, which was introduced by the Joint FAO/WHO Expert Committee on Food Additives in 1961, postulating that it should measure the amount of an additive in food that could be ingested orally on a daily basis over a lifetime without an appreciable health risk. To calculate the ADI, NOAEL is corrected by two certainty factors, one for extrapolating from animal to human, and another to account for interindividual variability in humans ( $\mathrm{Lu} \mathrm{1988;} \mathrm{Branen} \mathrm{and} \mathrm{others} \mathrm{2001;} \mathrm{Watson} \mathrm{2002).}$ Although widely used, certain problems and limitations of the NOAEL have been 
pointed out by several authors (Leisenring and Ryan 1992; Dorato and Engelhardt 2005).

The ADI is the starting point to establish the maximum amount of a certain additive to be included in each foodstuff, which can vary from a few milligrams to "quantum satis", and expressed as $\mathrm{mg}$ of additive per $\mathrm{kg}$ body weight $(\mathrm{mg} / \mathrm{kg} \mathrm{bw})$. quantum satis is a Latin word employed by the EFSA which determines that there is "no maximum numerical level specified and substances shall be used in accordance with good manufacturing practice, at a level not higher than necessary to achieve the intended purpose and provided the consumer is not misled." (Council Regulation (EC) $1333 / 2008)$.

In order to approve new additives or extend the usage of an approved one within the EU, a series of procedures has to be carried out, divided into 4 parts. The first regards the "Chemistry and specifications", where the additive must be rigorously identified according to its origin as a single substance, a simple or complex mixture, a polymer, a derivative of botanical sources or a nanomaterial. The manufacturing process, the methods of analysis in foods, and stability must also be clearly explained. The second part, "Existing authorizations and evaluation", refers to the extension of authorizations of already approved additives and intends to gather previous data regarding it. The third part "Proposed uses and exposure assessment" must estimate the dietary exposure based on the proposed uses and use levels considering age groups and the population of all the EU member states. Finally the "Toxicological Studies" encompass studies regarding the additive's effect on in vitro and in vivo scenarios. The latter includes metabolism/toxicokinetics, acute subchronic and chronic toxicity, as well as genotoxicity, carcinogenicity, reproduction, absorption, developmental toxicity, immunotoxicity, and hypersensitivity/allergy in various animal models. Human trials 
are only allowed after adequate data from animal and other related studies are deemed safe, and always used to define adjustment factors between animals and humans. Other specific studies may be required for certain cases (EFSA 2012b). The premarket testing of additives may not be enough to conclude their safety towards humans, fostering posterior studies, and if necessary, eventual banning, when their toxicity is proven. Adding to this, is the controversy surrounding some additives that are approved in some countries and restricted or banned in others and the public concern regarding the use of animals for toxicological assays. These factors, among others, induce distrust in some people towards additives, pressurizing companies to look for natural substitutes for chemical additives, even though these natural compounds must logically be subjected to the same treatment as chemical ones. Lack of knowledge in the population towards food additives also affects their acceptance.

\section{TYPES OF ADDITIVES}

Within the EU, food additives are divided into 26 functional classes, depending on their function in food: sweeteners, colorants, "preservatives", antioxidants, carriers, acids, acidity regulators, anti-caking agents, anti-foaming agents, bulking agents, emulsifiers, emulsifying salts, firming agents, flavor enhancers, foaming agents, gelling agents, glazing agents, humectants, modified starches, packaging gases, propellants, raising agents, sequestrants, stabilizers, thickeners and flour treatment agents (Council Regulation (EC) 1333/2008). The American approach of food additives narrows down the number of classes and allows additives to be mentioned in two or more classes. According to the FDA, there are more than 3000 food additives allowed in the USA, which are distributed into 6 groups: Preservatives, nutritional additives, coloring agents, 
flavoring agents, texturizing agents, and miscellaneous agents (Figure 1). The preservatives group is divided into three subgroups, although some additives may serve more than one function in foods: antimicrobials, antioxidants, and antibrowning agents. Within the flavoring agents group, there are three sub-groups: the sweeteners, the natural or synthetic flavors, and the flavor enhancers. The texturizing agents comprise emulsifiers and stabilizers. Finally, the miscellaneous agents are composed of many classes: chelating agents, enzymes, anti-foaming agents, surface finishing agents, catalysts, solvents, lubricants, and propellants (Branen and others 2001). Despite the various classes of additives and the different classifications used, they can be divided in 4 fundamental groups with regard to their origin and manufacture: natural additives (obtained directly from animals or plants); similar to natural additives (produced synthetically imitating natural ones); modified from natural (natural additives that are then modified chemically); and finally artificial additives (synthetic compounds).

The authors recognize that it would be impossible to totally review the more than 3000 food additives, thus the review will be focused on the most important ones, either based on their high consumption or due to the important functional properties they can provide to foods in which they are incorporated. Only the most import additives per class are described here.

\section{Preservatives}

This group is composed of antimicrobials, antioxidants, and antibrowning agents. The $\mathrm{E}$ numbers of the preservatives range from E200 to E399.

\section{Antimicrobials}

The antimicrobials are added to food for 2 purposes, a) to control natural spoilage of food (food control) and/or b) to avoid/control contamination by microorganisms, 
including pathogenic ones (of food safety concern) (Tajkarimi and others 2010). The main chemical antimicrobials used in food with quantum satis status are acetic acid (E260), potassium acetate (E261), calcium acetate (E263), lactic acid (E270), carbon dioxide (E209), and malic acid (E296). The antimicrobial additives with restricted uses are benzoic acid and benzoates (E210-E219; ADI $5 \mathrm{mg} / \mathrm{kg}$ bw), sorbic acid, and sorbates (E200-E209; ADI $25 \mathrm{mg} / \mathrm{kg} \mathrm{bw),} \mathrm{propionic} \mathrm{acid} \mathrm{and} \mathrm{propionates} \mathrm{(E280-E289;}$ quantum satis), nitrites (potassium nitrite E249; ADI $0.07 \mathrm{mg} / \mathrm{kg}$ bw, sodium nitrite E250; ADI $0.1 \mathrm{mg} / \mathrm{kg} \mathrm{bw}$ ), nitrates (sodium nitrate E251 and potassium nitrate E252; both with ADI 3.7mg/kg bw), and parabens (E214-E219; ADI $10 \mathrm{mg} / \mathrm{kg} \mathrm{bw}$ ), which are depicted in Table 1. Benzoic acid (E210), produced by oxidation of toluene, is a widespread antimicrobial agent, employed against yeast, bacteria, and fungi. It acts through membrane disruption and inhibition of metabolic reactions, stress, and accumulation of toxic anions inside the microbial cell (Brul and Coote 1999). It may be coupled to calcium, potassium, or sodium for different antimicrobial targets and effects. The main applications of sodium benzoate (E211) are soft drinks, fruit juices, sauces, pickles, edible coatings, seafood products, toothpastes, lotions, creams, and some pharmaceutical products (WHO 2000). This antimicrobial compound has been tested in vitro, and was regarded as nontoxic, but some authors found toxicity in the Drosphila SMART (somatic mutation recombination test) test, root tips of garlic (Allium sativum), as well as a clastogenic, mutagenic, and cytotoxic effect in human peripheral blood lymphocytes (Yilmaz and others 2008, 2009; Zengin and others 2011). In murine models, sodium benzoate decreased the release of leptin, helping to contribute to obesity, while also leading to malformation of zebrafish (Danio rerio) larvae (Tsay and others 2007; Ciardi and others 2012; Mangge and others 2013). Sodium benzoate has also been reported to intercalate with bovine thymus DNA at concentrations as low as 
$4.5 \times 10^{-5} \mathrm{~mol} \mathrm{~L}^{-1}$ (Zhang and Ma 2013a). Nair (2001) reviewed the risk of exposure of benzyl alcohol, benzoic acid, and sodium benzoate and concluded that, although being safe, in some studies regarding mice, malformations and toxicity effects were detected and dermal complications were known to occur in humans. Furthermore, due to the various applications of these compounds, the risk of inhalation could not be determined, and remained as an important and urgent matter to be further studied. In a study involving children (a group of 3-year-olds and another of 8/9-year- olds) exposed to sodium benzoate, a global hyperactivity aggregate was reported when compared to the control groups. Although pointing out interesting conclusions, this was not well accepted because sodium benzoate was mixed with food colorants, being difficult to determine which of the compounds was the responsible one for the hyperactivity or if a synergistic effect exists (McCann and others 2007). The same hyperactivity behavior was reported in a study involving college students who consumed sodium benzoate-rich soft drinks, validating the need for further studies regarding this compound (Beezhold and others 2012). In Portugal and Italy, surveys were carried out in order to discover if soft drinks contained benzoic acid or benzene residues. The results pointed out that both benzoic and sorbic acids were present above legal values in some cases, although not exceeding the acceptable daily intakes. In the case of benzene, it was found in some Italian soft drinks. Other surveys from Turkey analyzed both these antimicrobials in various foods and revealed that, in certain cases, benzoic and sorbic acids were detected in some samples above the maximum limit of the Turkish Food Codex (Lino and Pena 2010; Bonaccorsi and others 2012; Cakir and Cagri-Mehmetoglu 2013; Ulca and others 2013). Adams and others (2005) reported that the safety of benzyl derivatives in food was supported by the higher intake of those compounds in traditional foods rather than in the intentionally added flavorings. Benzyl alcohol and its derivatives (benzoic acid 
and sodium benzoate, among others) belong to the aryl alkyl alcohols, which apart from being food additives are also commonly used in fragrances, cosmetics, shampoos, soaps, and other toiletries as well as in household cleaners and detergents. Scognamiglio and others (2012) reviewed all the toxicological and dermatological research concerning in vitro, animal models, and human dermatological assays regarding absorption of benzyl alcohol, and referred to Besito and others (2012) for conclusions. These authors reviewed the toxicological and dermatological aspects of aryl alkyl alcohols used in fragrances, and determined that with all the data gathered, these compounds do not pose safety concerns in the declared levels of exposure. Still, very little research focuses on occupational exposure to these compounds, and future studies should take into consideration the combined effects of occupational and non-occupational (cosmetics, perfumes, shampoos) quantities absorbed by the skin (Schnuch and others 2011).

Although these reports seem unsettling, benzoates are necessary and the only way they will be removed as additives is when a substitute with the same effect and no toxicity is found. Without these compounds food spoilage and poisoning would have a much higher incidence.

While benzoates are used with acidic foods, sorbates can be employed in foods with higher $\mathrm{pH}$ values. Sorbic acid (E200), an organic natural compound, is the base molecule of 3 important antimicrobials: potassium sorbate (E202), sodium sorbate (E201), and calcium sorbate (E203). Among these molecules, sodium sorbate, although being allowed in the USA, is banned in the EU. Some in vitro studies have related the conjugated double bonds present in sorbic acid's structure as being prone to nucleophilic attack, turning it into a mutagenic compound. The interaction between sorbic acid and various amines was tested by Ferrand and others (2000) for mutagenic and genotoxic activities on HeLa cells and plasmid DNA, resulting in negative values, 
while another study found sodium sorbate toxic towards human lymphocytes at 400 and $800 \mu \mathrm{g} / \mathrm{mL}$ (Mamur and others 2012). Sorbic acid forms mutagenic compounds when in contact with nitrites, which are another kind of widely used antimicrobials (Binstok and others 1998), while potassium sorbate is also genotoxic to human peripheral blood lymphocytes at $1000 \mu \mathrm{g} / \mathrm{mL}$ (Mamur and others 2010), although these claims are controversial (Mpountoukas and others 2008). Jung and others (1992) also described sodium sorbate as being easily oxidizable, and therefore leading to the formation of 4,5oxohexenoate, which is mutagenic, while sorbic acid and its potassium sorbate are not.

Propionic or propanoic acid (E280) is a naturally occurring carboxylic acid that is used in food, especially bakery products, to avoid mold and other fungal contamination. There are not many studies regarding the toxicity of propionic acid or its salts, (sodium propionate, E281), calcium propionate (E282), and potassium propionate (E283), although it has been considered to suppress, in a dose-dependent manner, Th1-type immune response in human peripheral blood mononuclear cells in vitro. Sodium propionate has been stated as inducing abnormalities on the root tips of onion, while calcium propionate has been related to irritability, restlessness, inattention, and sleep disturbance in some children (Dengate and Ruben 2002; Türkoğlu 2008; Maier and others 2010). Nitrates (E240-E259) and nitrites (E249, E250) in which sodium nitrate (E251), potassium nitrate (E252), potassium nitrite, and sodium nitrite are the most important compounds. They are used in the meat industry, namely for curing. While nitrate was widely used in the past, nowadays it is restricted to specific slow meat curing. On the other hand, nitrites are used for various applications in several types of meat, namely for color formation, flavor enhancement, and antimicrobial activity. Nowadays, nitrites are considered the only food additive that can inhibit the development of the botulinum toxin, thus justifying their use in a benefit/risk scale in 
the food industry. The EFSA allows its use at the minimum possible dosage. Apart from being used as food preservatives, nitrites are also present in considerable quantities in non-treated vegetables and fruits. These compounds are also known to take part in the formation of nitrosamines (carcinogenic molecules resulting from the reaction of nitrites with secondary amines) posing a threat to consumers (Sebranek and Bacus 2007; Sindelar and Milkowski 2012). Nitrites are considered by some authors as being carcinogenic, while others refute this possibility and consider plant nitrites important for some physiological roles, such as supporting cardiovascular health and gastrointestinal immune function (Hord and others 2009). Although evidence supports both theories, it is widely accepted that the excess intake of nitrite is dangerous and has deleterious effects on human health, by oxidation of oxyhemoglobin to ferrihemoglobin, leading to methemoglobinemia (Cammack and others 1999). In order to counter these adverse effects, much research is being carried out to find alternatives to nitrites (Chow and Hong 2002; Chan 2011; Hord 2011). Paraben is a generic name for a group of food additives, which are alkyl esters of p-hydroxybenzoic acid. These compounds are widely used in food as antimicrobials, especially due to their absence of odor or and taste (Tavares and others 2009). Its effectiveness increases as a function of the alkyl group length. The most used compounds of this group are methyl paraben (E218; ADI $10 \mathrm{mg} / \mathrm{kg}$ bw), ethyl paraben (E214; ADI $10 \mathrm{mg} / \mathrm{kg} \mathrm{bw}$ ) and propyl paraben (E216; ADI $10 \mathrm{mg} / \mathrm{kg} \mathrm{bw}$ ). In the past, parabens were not considered mutagenic, but were known to cause chromosomal aberrations and contact allergy (Darbre and others 2004; Tavares and others 2009). Today, not without debate, they have been linked with reproductive decrease in men by interacting with the mitochondrial function of testicular cells. Epididymis sperm reserves and sperm concentration has also been reported to decrease in a dose-dependent manner when males are exposed to parabens. Other authors have 
reported that these compounds have no relation with the male reproductive system, and are readily metabolized into $p$-hydroxybenzoic acid, inside the body, which is not a toxic compound. Parabens have also been described as estrogenic disruptors and to be related with breast cancer in women, although, to this date many, conflicting theories exist (Oishi 2002; Harvey and Everett 2004; Meeker and others 2011; Aubert and others 2012). Castelain and Castelain (2012) concluded that methyl and ethyl parabens are safe to be used and did not find evidence of related health problems, while pointing out that propyl and butyl parabens should still undergo more studies in order to correctly assess their toxicity and potential harm to human health.

Sulfites are a group of molecules (the most common are sulfur dioxide, sodium and potassium bisulfite, and, sodium and potassium bisulfate) used in foods as antimicrobials and antibrowning agents. Their antimicrobial effect is carried out by the uptake of SH groups from sulfites into the microorganism's cell where they react with proteins, DNA, enzymes, while the antioxidant effect occurs by inhibiting both Maillard reactions and the enzyme polyphenol oxidase. Sulfites can act freely or be combined with organic acids, being used in wine making and in many other foodstuff that is prone to microbiological decay. The negative effects of sulfites are related with the destruction of vitamin B1 (thiamine) and to cause skin and respiratory sensitivities, such as dermatitis, urticaria, angio-edema, abdominal pain, diarrhea, bronchoconstriction, and fatal anaphylaxis (Rencüzoğullari and others 2001; Vally and others 2009; GarcíaGavín and others 2012). These symptoms can become more prevalent due to the large quantity of foodstuffs treated with sulfites, like canned goods, seafood, and dried fruits. In the EU and USA, all products that contain sulfites must show this information on the label. Many surveys have been carried out in various countries, with Belgium and New Zealand reporting danger to individuals who consume high quantities of sulfited wine 
(Cressey and Jones 2009; Vandevijvere and others 2010). In Turkey, some foodstuffs intended for export displayed quantities of sulfites above the legal limit, while Korea reported that the consumption of sulfites for individuals aged between 30 and 64 is above that of the other age groups (Suh and others 2007; Ulca and others 2011). More research should be carried out to determine the real effect of sulfites to human health, especially when used as a food additive, since food is one of the main, but not the only, source of exposure to these compounds.

\section{Antioxidants}

The antioxidants are another subgroup of the preservatives, essential to extend the shelflife of many foodstuffs. Antioxidants prevent the oxidation of molecules by donating a hydrogen atom or an electron, becoming themselves reduced, in the radical form, but contrary to other radicals, antioxidants when in radical form are stable and do not allow further reactions to take place, therefore preserving the status quo of the system (Carocho and Ferreira 2013a). Food antioxidants are used for extending shelf-life and impeding decay while not adding taste or odors to food or modify appearance (Nanditha and Prabhasankar 2009). Lipid peroxidation and rancidification are the most common types of oxidation occurring in foodstuffs while they are stored. The most commonly used antioxidants with quantum satis status are ascorbic acid (E300), sodium ascorbate (E301), calcium ascorbate (E302), fatty acid esters of ascorbic acid (E304), tocopherols (E306), $\alpha$-tocopherol (E307), $\gamma$-tocopherol (E308), $\delta$-tocopherol (E309), lecithins (E322), sodium lactate (E325), potassium lactacte (E326), calcium lactate (E327), citric acid (E330), sodium citrate (E331), potassium citrate (E 332), calcium citrate (E333), tartaric acid (E334), sodium tartrate (E335), potassium tartrate (E336), sodium potassium tartrate (E337), sodium malate (E350), potassium malate (E351), calcium malate (E 352), calcium tartrate (E354) and triammonium citrate (E380). As shown in 
Table 2, the most common chemical antioxidants added to food to inhibit lipid peroxidation and rancidification are butylated hydroxyanisole (BHA, E320; ADI 0.5 $\mathrm{mg} / \mathrm{kg} \mathrm{bw}$ ), butylated hydroxytoluene (BHT, E321; ADI $0.05 \mathrm{mg} / \mathrm{kg}$ bw), propyl galate, (PG, E310; ADI $1.4 \mathrm{mg} / \mathrm{kg}$ bw), ethoxyquin (EQ, E324; ADI $0.005 \mathrm{mg} / \mathrm{kg}$ bw) and tertbutylhydroquinone (TBHQ, E319; ADI $0.7 \mathrm{mg} / \mathrm{kg} \mathrm{bw}$ ). BHA has been used since the 70's as an effective antioxidant in food with numerous studies describing its toxicity against lab models. Whysner and Williams (1996a) described BHA's toxicity as being species-specific for murine models and safe for human consumption due to the lack of a forestomach in the human species that is sensitive to this antioxidant. More murine assays were carried out until 2011, when the EFSA reviewed the literature and published a revised admissible daily intake (ADI) that was not likely to be exceeded by the population. Still, much controversy arises from the consumption of BHA and studies have to continue to bring more facts into the discussion (Jeong and others 2005; EFSA 2011; Ali and Suzuki 2012; Carocho and Ferreira 2013a; Vandghanooni and others 2013). BHT, due to its similarity with BHA has suffered the same fate, with many studies pointing out its carcinogenity and deleterious effect on murine and human health. The EFSA also reviewed the daily intake of BHT, placing it at $0.05 \mathrm{mg} / \mathrm{kg} \mathrm{bw}$, which is low if compared with the one of BHA $(0.5 \mathrm{mg} / \mathrm{kg} \mathrm{bw})$. Still, as with BHA, some researchers continue to find deleterious effects with BHT, while others have demonstrated its anticarcinogenic effects (McFarlane and others 1997; Williams and others 1999; Botterweck and others 2000; Engin and others 2011; EFSA 2012a; Carocho and Ferreira 2013a). Propyl gallate (PG) is used to prevent rancidity in meat products, and due to its water solubility it can form complexes with iron salts and darken some foodstuffs, and therefore is usually added with citric acid to inhibit this phenomenon (Jacobi and others 1998; Branen and others 2001). PG can also act in 
synergism with BHA and BHT, but not with TBHQ. PG is prepared by esterification of gallic acid with propyl alcohol, and, since its discovery in 1948, and ever since, it has had controversial and antagonistic effects, as reported by many authors. Some claim PG as chemotherapeutic, nephroprotective, and cytotoxic to HeLa cells, among other beneficial activities, while others point out its effect as a xenoestrogen, a contact dermatitis precursor, mutagen inducer, and that its antioxidant potential can, under certain conditions turn prooxidant (Tayama and Nakagawa 2001; Chen and others 2011; Zurita and others 2007; Amadasi and others 2009; Han and Park 2009; Tian and others 2012). Ethyl gallate, octyl gallate, and dodecyl gallate are very similar to PG and execute the same effect in food, although being less used and, therefore, less researched. Ethoxyquin (EQ) (E324; ADI $0.005 \mathrm{mg} / \mathrm{kg} \mathrm{bw}$ ) is a quinolone-based antioxidant that is not permitted to be added to human food, only used in domestic and farm animal feed. This compound has been reported to induce dermatitis in animals and humans, as well as being a promoter of certain types of cancer. Although there is no immediate danger from EQ to humans, since it is not allowed in food, there is still a latent risk, which derives from the excess present in the ingested animal tissue, thus further studies should be carried out to regulate its indirect potential hazard (Błaszczyk and others 2003; Rodríguez-Trabado and others 2007; Błaszczyk and others 2013; EFSA 2013a).

\section{Antibrowning agents}

Antibrowning agents are used as food additives to prevent food browning, which can occur at any moment during handling, processing and storage. There are 2 types of browning, enzymatic and nonenzymatic browning. In the former, the enzyme polyphenol oxidase catalyzes the conversion of polyphenols to quinones with further breakdown of these compounds, ultimately darkening the color of the food (Branen and others 2001). Nonenzymatic browning occurs in sugar caramelization and in the 
Maillard reaction between carbonyl and free amino groups, producing melanoidin pigments in various foodstuffs (Branen and others 2001). Among the most used antibrowning agents are sulfites, covered in the previous section. The alternatives to sulfites are natural compounds, like ascorbic acid-based formations, such as erythorbic acid (E315; $5 \mathrm{mg} / \mathrm{kg} \mathrm{bw})$; cysteine (E920; quantum satis), which is an aminoacid and reacts with quinolone intermediates inhibiting further formation of compounds; some phenolic acids, and finally 4-hexylresorcinol (E586; ADI not specified), an organic compound which is only regulated in shrimp (Branen and others 2001; Oms-Oliu and others 2010).

\section{Nutritional additives}

Although considered by some authors, nutritional additives should not be considered as such, since they confer nutritional value to the food where they are incorporated, and, should rather be considered as enrichments to foodstuffs. The consumption of these enriching compounds has increased in recent years due to health concerns of the population and its relation with nutrition. The functional and nutraceutical activities of some nutrients have been gaining interest from both the scientific community and the food industry, resulting in its incorporation in certain foodstuffs, adding value to them. These nutritional enrichments are natural ones, and can be vitamins, amino acids, fibers, fatty acids, and polyphenols, among others. The sources can vary depending on plant, mushroom, animal, or even synthetic origin (Branen and others 2001).

\section{Coloring agents}

Coloring agents or food dyes are used to alter or confer colors to food, in order to increase its attractiveness towards consumers. The only dye with quantum satis status is calcium carbonate (E170), which confers a white color to food. Dyes have been used for 
a long time in the food industry, but not without controversy and disagreement regarding their health effects (Branen and others 2001; Msagati 2013). Some dyes, like amaranth (E123; ADI $0.15 \mathrm{mg} / \mathrm{kg} \mathrm{bw}$ ), carmosine (E122; ADI $4 \mathrm{mg} / \mathrm{kg} \mathrm{bw}$ ) and others are banned in some countries, but not in others; for instance, both these compounds are banned in the USA and not in the EU, while fast green (FD\&C Green No. 3) is forbidden to be used within the EU and legally added to food in the USA. There are 5 groups of coloring agents: the azo compounds, the chinophthalon derivatives of quinoline yellow, the triarylmethane group, xanthenes, and the indigo colorants (Sarikaya and others 2012).

\section{Azo compounds}

Regarding the azo group, it has many different colors, and all of them display the functional group R-N=N-R', in which R and R' can be either aryl or alkyl (Stolz 2001; Chudgar and Oakes 2003). Among them, some of the most used are tartrazine, known in the USA as FD\&C Yellow No.5 (E102; ADI $7.5 \mathrm{mg} / \mathrm{kg} \mathrm{bw),} \mathrm{sunset} \mathrm{yellow,} \mathrm{known} \mathrm{in}$ the USA as FD\&C Yellow No. 6 (E110; ADI $2.5 \mathrm{mg} / \mathrm{kg}$ bw), allura red, known in the USA as FD\&C Red No. 40 (E129: ADI 7 mg/kg bw), amaranth (E123; ADI 0.15 mg/kg bw), and carmosine (E122; ADI 4 mg/kg bw) (Fennema 1996). These compounds are described in Table 3. The azo compounds, with the $\mathrm{N}=\mathrm{N}$ functional group and aromatic rings linked to them are reductively cleaved into aromatic amines, with some of these aromatic amines being toxic, mutagenic, and carcinogenic (Chung 2000; Zhang and Ma 2013b). Tartrazine is probably one of the most controversial colorants, with some studies classifying it as a DNA binder, toxic to human lymphocytes (4 mM), a contributor to primary biliary cirrhosis, lipid peroxidation promoter by production of malondialdehyde, and reducer of superoxide dismutase and glutathione peroxidase in mice $(500 \mathrm{mg} / \mathrm{kg}$ ) (Amin and others 2010; Mpountoukas and others 2010; Gao and 
others 2011; Axon and others 2012). Other studies regard tartrazine as safe to be consumed in the admissible daily intake, posing no harmful effect in murine models and in humans (Tanaka 2006; Moutinho and others 2007; Tanaka and others 2008; Poul and others 2009). Another widely used azo dye is sunset yellow, which is produced from aromatic compounds derived from petroleum hydrocarbons. This compound, as tartrazine, has been related to genotoxicity in murine models with memory and learning deficits on the offspring as well as immunomodulatory and xeno-estrogenic effects (Axon and others 2012; Sayed and others 2012; Ceyhan and others 2013; Yadav and others 2013). Petroleum-derived allura red has been subject to many toxicologic studies. Some authors consider it as an impeding factor of memory and learning in infant rats, inducing also damage to rodent colons $(10 \mathrm{mg} / \mathrm{kg})$ (Tsuda and others 2001 ; Shimada and others 2010; Ceyhan and others 2013). The EU has reviewed its opinion on allura red twice, concluding in the second statement that there is a possibility that it can be genotoxic, nevertheless some existing studies point otherwise (AbramssonZetterberg and Ilbäck 2013). Amaranth, another dye derived from petroleum, has been extensively investigated in the past and was banned in the USA for being allegedly carcinogenic. It is approved in the EU and some other countries. Recent studies, using comet assay, have described it as inducing damage in the colon of rats (10 to 100 $\mathrm{mg} / \mathrm{kg}$ ). Moreover, using a somatic mutation and recombination test, amaranth proved to induce genotoxicity to human lymphocytes $(8 \mathrm{mM}$ ) (Sasaki and others 2002; Mpountoukas and others 2010; Sarikaya and others 2012), while others have found no evidence of these effects in murine models (Poul and others 2009). Carmoisine, another widely used dye which is forbidden in the USA has also been reported as being responsible for biochemical markers alteration in murine vital organs, modification of the secondary structure of serum proteins (human serum albumin and bovine serum 
albumin), as well as promoting conformation changes in DNA of bovine models (Amin and others 2010; Arvin and others 2013; Datta and others 2013).

\section{Chinophthalon derivatives}

Quinoline yellow (E104; ADI $10 \mathrm{mg} / \mathrm{kg}$ bw) is a quinophthalone synthetic dye chemically prepared by mixing sodium disulfonates, monosulfonates, and trisulfonates. This compound has been reported to cause urticaria, asthma, rashes, and hyperactivity. It also alters the conformation of bovine serum albumin. A case of quinoline yellowderived skin eruption was documented in 2013 (Branen and others 2001; Macioszek and Kononowicz 2004; Shahabadi and others 2012; Leleu and others 2013).

\section{Triarylmethane group}

The triarylmethane group relies on triphenylmethane backbones to produce different compounds like brilliant blue, known in the USA as FD\&C Blue No. 1 (E133; ADI 12.5 $\mathrm{mg} / \mathrm{kg}$ bw), fast green (E143; ADI $12.5 \mathrm{mg} / \mathrm{kg}$ bw), patent blue (E131; ADI $1 \mathrm{mg} / \mathrm{kg}$ bw), and brilliant black (E151; $1 \mathrm{mg} / \mathrm{kg}$ bw) among others (Table 4). Of these, brilliant blue and patent blue are the most common additives, although patent blue is banned in the USA, and no permission was sought for brilliant black, while fast green is banned in the EU. These colorants are not readily absorbed by our bodies, in fact, $95 \%$ of them are present in feces, and there are no reports of deaths due to human improper absorption (Gaur and others 2003). Reports on changes in mitochondrial respiration have been described (Reyes and others 1993), as well as somatic mutation in Drosophila melanogaster wing spot test $(25 \mathrm{mg} / \mathrm{mL}$ of patent blue, $12.5 \mathrm{mg} / \mathrm{mL}$ amaranth) (Sarikaya and others 2012; Tanaka and others 2012). Some authors consider that the consumption of lollipops with brilliant and patent blue colorants by children is 
dangerous due to their absorption through the lingual mucosa (Lucová and others 2013), and with negative effects on children who are the greatest consumers of these products.

\section{Xanthenes group}

The xanthenes group is comprised of erythrosine, known in the USA as FD\&C Red No. 3, (E127; ADI $0.1 \mathrm{mg} / \mathrm{kg} \mathrm{bw}$, fluoresceine, eosines, and rhodamines. Erythrosine is allowed in both the USA and EU, while fluorescine is banned in the EU. This dye is a poly-iodinated compound that has been related to alteration in childhood behavior and thyroid function due to high iodine content (Chequer and others 2012; Lakshmi and Buchwald 2013). Other studies pointed out that this compound could induce toxicity to mice testicles $(689 \mathrm{mg} / \mathrm{kg})$ and alter behavior patterns in these models. Recently it has also been found to alter DNA structures, to display toxicity on human lymphocytes, HepG2 $(50 \mu \mathrm{g} / \mathrm{mL})$ and to promiscuously inhibit protein-protein binding (Aziz and others 1997; Tanaka 2001; Mpountoukas and others 2010;).

\section{Indigo colorants}

The indigo colorants derive from the indigo dye, known as FD\&C Blue No. 2 in the USA, which was initially extracted from the shrub Indigofera tinctoria. Today they are chemically produced, and adverse reactions rarely occur in the typical quantities added to food.

Food colorants have been subject of many extensive studies. One of the most controversial was "The Southampton Study", in which a cocktail of food colorings was given to a group of children in their meal, with posterior comparison of the behaviour patterns to a placebo group. The researchers found evidence of attention deficit hyperactivity disorder (ADHD) for the group consuming the colorants. This study was highly contested by both the advisory body of the United Kingdom's Food Safety 
Authority (FSA) and the EFSA, but the public advocacy groups and the media promoted a voluntary ban on the implicated colors. A couple of years later, a follow-up study concerning food additives in Irish children pointed out that, comparatively to the Southampton study, children would never be exposed to such high doses of additives, helping their readmission. In 2008, the EU published regulation 1333 pointing out that some additives should clearly state possible negative effects on concentration activity of children (Council Regulation (EC) 1333/2008).

The conflicting results for virtually all the food colorants are quite preoccupying and should motivate the competent institutions to proceed with regulation, in order to dissipate consumer doubts. Although many studies have been published regarding colorants, very few considered interactions among colorants and their dangerous effects on health. Two studies have pointed out the deleterious synergistic effects of colorants in neuronal cell lines in vitro (Lau and others 2006; Park and others 2009). Although subject of much controversy, colorants play an important role in the food industry, and the pressure for natural ones has been increasing. There are some alternatives with good results that are slowly approved in both the USA and EU. Carotenoids, anthocyanins, annatto, and paprika are examples of natural colorants that can substitute their synthetic counterparts. The main drawbacks of these natural compounds are instability due to $\mathrm{pH}$ and temperature, loss of color by oxidation, the need for higher quantities in comparison to chemical ones and the higher cost of manufacture (Hendry and Houghton 1996; Downham and Collins 1999; Calvo and Salvador 2000; Delgado-Vargas and others 2000; Giusti and Wrolstad 2002; Scotter 2009; Msagati 2013). Although colorants are better regulated and safer, further research is still needed to mitigate the faults in colorants, either by improving the safety of approved ones or by discovering new.

\section{Flavoring agents}


The flavoring agents are additives used to alter the taste of food either by enhancing it, sweetening, or completely changing the final taste of the produced foodstuff. The flavoring agents group is divided into 3 subgroups, the sweeteners, the natural and synthetic flavors, and the flavor enhancers.

\section{Sweeteners}

The sweeteners are a group of compounds that confer sweetness to food. These can be nutritional sweeteners like sucrose, fructose (high-fructose corn syrup) and glucose or artificial non nutritive sweeteners. There are no sweeteners with a quantum satis level. The most widespread non nutritive sweeteners are saccharin (E954; ADI $2.5 \mathrm{mg} / \mathrm{kg}$ bw), cyclamates (E952; ADI $350 \mathrm{mg} / \mathrm{kg} \mathrm{bw}$ ), aspartame (E951; ADI $50 \mathrm{mg} / \mathrm{kg} \mathrm{bw}$ ), acesulfame K (E950; ADI $15 \mathrm{mg} / \mathrm{kg} \mathrm{bw}$ ), and sucralose (E955; ADI $15 \mathrm{mg} / \mathrm{kg} \mathrm{bw}$ ), as depicted in Table 5 (Branen and others 2001). Saccharin is the oldest low-calorie sweetener, discovered in 1878, being 300 times sweeter than sugar. In the past, saccharin was thought to be related to human bladder cancer, but after intense research this idea was abandoned, with only a specific species (mouse) tumorigenicity prevailing, with the results being corroborated in 2002 (Whysner and Williams 1996b; Dybing 2002). Saccharin's main objective, like all non-caloric sweeteners, is to confer sweetness to food without adding calories, making them edible by children, diabetic patients, and people who want to reduce calorie intake. Despite this noble objective, various studies have related saccharin with an increase in weight gain of mice consuming saccharin when compared to groups fed with sucrose (Swithers and others 2010; Feijó and others 2013). Cohen-Addad and others (1986) pointed out the capacity of saccharin to cross the human placenta, and hypothesized that the presence of this compound, both in utero and ex utero, could increase the incidence of neoplasms. Although the carcinogenicity effects of this compound have been ruled out, it is still 
advisable to continue studying different types of activities of saccharin in the human body taking advantage of the new technologies that can help to uncover potential new dangerous interactions (Bandyopadhyay and others 2008).

Cyclamate is another low-calorie sweetener, it was discovered in 1937 and was joined with saccharin in a 10:1 blend to remove its unpleasant metallic aftertaste. In the USA, cyclamates are not allowed in food. After its discovery, cyclamate was related to bladder cancer in mice, which was later ruled out after many studies with different animals (Takayama and others 2000). Today, some studies have described retardation of fetal development and hypertrophy in the exocrine pancreas of rat fetuses when exposed to cyclamate (Martins and others 2010). Cyclamate is differently metabolized in humans. Some individuals are able to convert cyclamate to cyclohexylamine, which is known to have some carcinogenic effects; nevertheless others simply do not metabolize it (Renwick and others 2004). This difference in metabolization and the fact that cyclohexylamine has been proven to induce testicular atrophy in rats are the main concern among scientists.

Aspartame, discovered in 1965, is another widespread low-calorie sweetener. It is composed of phenylalanine and aspartic acid linked to methanol. Extensive studies have been carried out regarding aspartame, and while some vouch for its safety others find troubling conclusions (Ashok and others 2013; EFSA 2013b; Rycerz and JaworsakaAdamu 2013). In a brief communication after the first conference on aspartame, Renwick and Nordmann (2007) pointed out that the risk assessment gave an unbalanced impression to regulators and consumers, and that future quantitative risk-benefit analyses should be able to provide more comprehensive advice. After this, other studies have shown that long-term consumption of aspartame may lead to hepatocellular injury and alterations in liver antioxidant status while also altering behavior in rats (Abhilash 
and others 2011; Ashok and others 2013), although not without intense debate. Aspartame present in stored food can, at high temperatures and $\mathrm{pH}$ above 6, break down into its metabolite, deketopiperazine, which is a major carcinogen to the central nervous system and is being actively investigated (Rycerz and Jaworsaka-Adamu 2013).

Acesulfame K, or acesulfame potassium was discovered in 1967. It is not metabolized by the human body, therefore does not contribute to potassium uptake. Mukherjee and Chakrabart (1997) described this compound first as being genotoxic in rats, but later, after repeating some assays, refuted the previous conclusions and considered acesulfame $\mathrm{K}$ as safe, although some authors pointed out that a long-term study should be carried out (Karstadt 2006; Soffritti 2006). Sucralose is an artificial sweetener very similar to sucrose, in fact, only $3 \mathrm{OH}$ groups are substituted by $\mathrm{Cl}$ atoms. Discovered in 1976, after several years of research, it was approved for consumption with no adverse effects reported in the various animal model studies performed, even at long-term exposure, seen as though the human body does not recognize sucralose as a sugar and therefore does not metabolize it (Baird and others 2000; Roberts and others 2000; Sims and others 2000). In 2008, a study carried out with rats fed with sucralose pointed out various adverse effects, including reduction in beneficial fecal microflora, increased fecal $\mathrm{pH}$, and enhanced expression levels of P-glycoprotein and cytochrome $\mathrm{P} 450$ (Abou-Donia and others 2000), although this study was highly contested by an expert panel (Brusick and others 2009). Recent research has corroborated the previous findings of non toxicity or carcinogenicity (Brusick and others 2010; Viberg and Fredriksson 2011). The sub-group of sweeteners offers many conflicting results and different points of view, but have led to several research articles assuring the safety of some artificial sweeteners and pointing out others still demanding further research (Weihrauch and Diehl 2004; Kroger and others 2006; Brown and others 2010; Swithers and others 2010; 
Tandel 2011; Shankar and others 2013). In the meantime, natural sweeteners have become increasingly prevalent in modern diets, for their reduced caloric contribution. Among them, sucrose, fructose (high-fructose corn syrup), thaumatin, and stevia are some of the most important. In the EU, sucrose and fructose are not considered as food additives, rather as ingredients, due to the definition of food additives within the union "Food additives are substances that are not normally consumed as food itself but are added to food intentionally for a technological purpose described in this Regulation, such as the preservation of food" (EFSA 2008). In the USA, these sugars are approved, and added as additives to food "Food additives includes all substances not exempted by section 201(s) of the act, the intended use of which results or may reasonably be expected to result, directly or indirectly, either in their becoming a component of food or otherwise affecting the characteristics of food" (CFR 2003; Bray and others 2004; Anton and others 2010). Thaumatin is a polypeptide extracted from the Thaumatococcus danielli plant, and first isolated in 1972. It is about 3000 times sweeter than sucrose and consists of two protein components, thaumatin I and thaumatin II. It is defined as GRAS in the USA, has an E number of 957 and a "not specified" ADI. Thaumatin is used as a sweetener, but is also applied as a flavor enhancer, and due to being a protein, it is rapidly digested. This compound has been studied and no reports of allergic reactions, mutagenic or teratogenic effects or toxic towards rats, dogs and humans were reported (Gibbs and others 1996; Branen and others 2001; Watson 2002). Stevia is a natural sweetener, extracted from the plant Stevia rebaudiana, a shrub endemic to North and South America. Stevia is 300 times sweeter than sucrose, and is composed of 8 sweet diterpene glucosides (stevioside, steviolbioside, rebaudiosides (A, B, C, D, E) and, dulcoside A. In the USA, stevia is a GRAS sweetener and is used in beverages, deserts, and sauces, among others. In the EU stevia is known as steviol 
glucosides, and uses the identifier E960. Stevia has tested negative for carcinogenic and genotoxic tests, as well and not having negative effects for reproductive and developmental studies (Koyama and others 2003; Kroger and others 2006; Carakostas and others 2008; EFSA 2010a; Lemus-Mondaca and others 2012).

\section{Natural and synthetic flavors}

Natural and synthetic flavors are mixtures of several chemicals used to substitute the flavor of foods. In most cases, these mixtures mimic the flavor of natural ones. Some additives of this group also carry out other functions in food, like antimicrobial activity, gelling properties, and others. There are more than 1700 natural and synthetic compounds available to flavor foods. Within this large number, acidulants play an important role by reducing the overall $\mathrm{pH}$ of the food. Most of these acidulants are organic acids, some of them do not present uses restriction (quantum satis) like acetic (E260), lactic (E270), malic (E296), citric (E330), propionic (E280), succinic (E363; ADI not specified), while others present maximum amounts permitted with ADI established, as fumaric (E297; ADI $6 \mathrm{mg} / \mathrm{kg} \mathrm{bw}$ ), tartaric (E334; ADI $30 \mathrm{mg} / \mathrm{kg} \mathrm{bw}$ ), and adipic (E355; ADI $5 \mathrm{mg} / \mathrm{kg}$ bw) acids (Branen and others 2001).

\section{Flavor enhancers}

Flavor enhancers are used to magnify, supplement, or enhance food flavor, but don't contribute with their own flavor. The most used flavor enhancers are glutamic acid (E620; ADI not specified), monosodium glutamate or MSG (E621; ADI not specified), disodium inosinate (E631; ADI not specified), and disodium guanylate (E627; ADI not specified). Monosodium glutamate is a salt of glutamic acid, a naturally occurring aminoacid. It is used in food to enhance its natural flavor and to produce the umami flavor (pleasant savory taste), either alone or in synergy with disodium inosinate or 
disodium guanylate. Glutamic acid is a known excitotoxin (molecules that can impair or destroy nerve cells by excessive stimulation), therefore it was involved in a long-term controversy. After this effect was proven in murine models, scientists extrapolated to primates and considered that these were not affected by it. Others considered that humans were affected by them, especially at a young age, and that, even though glutamic acid alone could not induce damage, the overall daily consumption of all possible excitotoxins should be taken into consideration (Olney 1990, 1994). In 2000 a review of previous safety evaluations by the FAO, WHO, and the Scientific Committee for Food towards monosodium glutamate was published. It concluded that, despite a part of the population being sensible to it, monosodium glutamate could be consumed without any concern (Walker and Lupien 2000). Recently, other effects on murine models and on humans have been attributed to monosodium glutamate, namely, induction of lipid peroxidation, impairment of synaptic plasticity of mice neurons, deleterious effects of murine oocytes, and increase in the overweight development of Chinese adults (Sanabria and others 2002; Eweka and Om'Iniabohs 2011; He and others 2011; Singh and Ahluwalia 2012), while other scientists found no correlation between monosodium glutamate and Chinese population obesity and that supplementation of food of postweaning pigs is safe and improves growth performance (Shi and others 2010; Rezaei and others 2013). Disodium inosinate and disodium guanylate are used in fewer foodstuffs and therefore are less researched, although some claims exist against their use in children's food.

\section{Texturizing agents}

Texturizing agents are chemicals added to food in order to modify the overall texture or mouthfeel of foodstuffs. The 2 main groups within the texturizing agents are emulsifiers and stabilizers. 


\section{Emulsifiers}

The primary role of emulsifiers is to maintain emulsions (mixtures of two immiscible liquids) in good dispersion. By presenting a balance between hydrophobic and hydrophilic groups, they surround the oil and other immiscible substances present in the foodstuff avoiding their "clumping". Emulsifiers with quantum satis status are: lecithins (E322), calcium tartrate (E354), alginic acid (E400), sodium, potassium, ammonium, and calcium alginates (E401-404), agar (E406), carrageenan (E407), processed euchema seaweed (E407a), locust bean gum (E410), guar gum (E412), tragacanth (E413), gum arabic (E414), xantham gum (E415), tara gum (E417), gellan gum (E418), glycerol (E422), konjac (E425), pectins (E440), celluloses (E461- 466 and 469), sodium, potassium, calcium, magnesium, mono- and diglycerides of fatty acids (E470a, 470b), acetic, lactic, citric, tartaric acid esters of mono- and diglycerides of fatty acids (E472a 472d), mono- and diacetyl tartaric acid esters, and mixed mixed acetic and tartaric acid esters of mono- and diglycerides of fatty acids (E472e, E472f) (Branen and others 2001; Council Regulation (EC) 1129/2011, Rohman and others 2013). Lecithins are naturally occurring phospholipids that have excellent emulsifying capacities, cholesterollowering properties, and no reported toxicity (Iwata and others 1993; Wilson and others 1998). Sorbitan, also known as polysorbate, consists of compounds containing polyoxyethylene ethers of mixed partial oleic acid esters of sorbitol anhydrides and related compounds. Sorbitan is efficient as an emulsifying agent in food, although there are some reports of neuron and cytotoxicity in some types of cells $(10 \mu \mathrm{g} / \mathrm{mL})$ and increased susceptibility to oxidative stress in murine models among other aspects (Tatsuishi and others 2005; Ema and others 2008; Eskandani and others 2013). Carboxymethyl cellulose is a cellulose derivative with carboxymethyl groups bound to some of the glucopyranose monomer hydroxyls, frequently used in various foodstuffs. 
No records of toxicity have been found for this emulsifier. Polyglycerol esters are also used for their emulsifying properties, with, polyglycerol polyricinoleate one of the most widespread. Various assays were conducted with this compound in murine and human models, and no toxicity or carcinogenicity was detected (Smith and others 1998; Wilson and Smith 1998). Propylene glycol is another emulsifier produced from the reaction of propylene oxide with an alcohol of choice in the presence of a catalyst. Propylene glycol is used as a food emulsifier, but also employed in the cosmetic and pharmaceutical industries. Despite some controversial claims regarding toxicity in the 70's and 80's, this compound can be consumed without concern (Thomas and others 2004; Spencer 2005; Werley and others 2011).

\section{Stabilizers}

Stabilizers and emulsifiers are often the same compound displaying both effects, although one of them is carried out more effectively. Quantum satis stabilizers are alginic acid (E400), sodium, potassium, ammonium, and calcium alginates (E401-404), carrageenan (E407), locust bean gum (E410), guar gum (E412), tragacanth (E413), gum arabic (E414), xantham gum (E415), gellan gum (E418), pectin (E440), invertase (E1103), polydextrose (E1200), oxidized starch (E1404) and monostarch phosphate (E1410). Some of the most used stabilizers are listed on Table 6. These compounds are added to confer and maintain the desired food texture, as well as to prevent evaporation and deterioration of volatile flavor oils. Pectin is a naturally occurring heteropolysaccharide contained in plant cell walls. This compound has demonstrated excellent stabilizing properties in foodstuffs and no reported toxicity has been found (Akhtar and others 2002; Leroux 2003). Alginates (potassium, sodium, and calcium) derive from alginic acid, and have gained much interest in recent decades for their natural origin in brown seaweeds or algae and no reported cases of toxicity. Alginates 
are hydrophilic colloidal carbohydrates that are used in the food industry due to their unique colloidal properties, which include thickening, stabilizing, suspending, gel producing, and emulsion stabilizing. In recent years, alginates have been used for microencapsulation and production of biofilms (Bouyer and others 2012). Carrageenans are a family of polysaccharides which are also extracted form seaweeds (kelp) and widely used in the food industry as a thickener, stabilizer, and texturizer. Up to 2001, very few reports on their toxicity existed until Tobacman (2001) described carrageenan as posing a carcinogenic risk to humans after detecting tumors in colons of animal models. Immediately after this study many others disproved the carcinogenicity of carrageenan, concluding that the carrageenan added to food is not carcinogenic, suggesting a confusion between carrageenan and poligeenan (degraded carrageenan) which is not used in the food industry (Weiner and others 2007). Recently, other studies have described carrageenan as altering sulfatase activity in cells, therefore changing vital cell processes (Yang and others 2012).

\section{Miscellaneous agents}

Miscellaneous agents are additives that are added to certain foodstuffs for a specific outcome and that are not included in the other described additive groups. Examples of miscellaneous additives are chelating agents, enzymes, antifoaming agents, surface finishing agents, catalysts, solvents, lubricants, and propellants (Branen and others 2001).

MOVING THE ADDITIVES TO THE EXTERIOR. EDIBLE COATINGS AND FILMS. 
Since the early 90's edible coatings and films containing antimicrobials, antioxidants and other bioactive compounds have been researched and used to extend shelf life of food and avoid spoilage. This technology is usually applied in minimally processed food, vegetables, fruit and meat, but also to other matrices like medication pills, sweets and even french fries. The advantages of this technology and the recent developments in food processing along with the demand for less additives in food has helped this area of research to develop. The main difference between coatings and films is that the latter are used as covers, wraps or separation layers, while the coatings are considered part of the final product, and are designed to protect or enhance it. The main benefits of edible coatings and films are the extension of the shelf life of the foodstuff, the addition of beneficial compounds like vitamins and antioxidants in the films, the environmental friendliness of the materials used, and the potential enhancement of the food taste. In terms of disadvantages, the main issues with this technology are related to the uneven thickness of the films which can lead to irregular dispersion of the active constituents. This can also occur if the food is not spatially uniform, which can lead to unprotected spots, leaving the foodstuff prone to contamination or decay. In terms of their components, edible films are divided into 3 categories: hydrocolloids (containing proteins, polysaccharides or alginates), lipids (containing fatty acids, acylglycerols or waxes) and finally composites, which contains compounds from both categories (Guilbert and others 1996; Debeaufort and others 1998; Lin and Zhao 2007; Bourtoom 2008; Skurtys and others 2010; Han 2013). There are some commercially available coatings, like chitosan, calcium pectinate, calcium ascorbate, wheat gluten, calcium acetate, sucrose esters and corn protein which are already added to foodstuffs (Dutta and others 2009; Embuscado and Huber 2009; Elsabee and Abdou 2013). One of the most researched compounds for edible films is chitosan, due to its combined antibacterial and 
antifungal effects, although it does have some limitations in terms of mechanical properties and vapor permeability. Pectins have also displayed interesting results (Espitia and others 2014). Other individual compounds extracted from plants, like carvacrol and methyl cinnamate have been tested in edible films, along with natural extracts of fruits and vegetables (lemon, orange, oregano, thyme, among others) with satisfactory results (Ponce and others 2008; Iturriaga and others 2012; Peretto and others 2014).

In order to overcome the limitations of this technology, future research should focus on tailor-made coatings and films, which are specific for the foodstuff rather than find the ideal compound or compounds for different foodstuffs (Valencia-Chamorro and others 2011).

NATURAL ADDITIVES. THE FUTURE OR THE SOURCE OF MORE CONTROVERSY?

The era of natural food additives has started, some consumers deliberately choose minimally processed foods over processed ones, and when they have to choose processed food they will generally select one with fewer additives and/or containing natural additives. Although the natural additives do not always represent a benefit compared to chemical ones, in most cases they are believed to be healthier, can carry out various functions in the food, and confer added value (bioactivity, nutraceutical). Natural additives are compounds, groups of compounds, or essential oils from plants that are already used empirically by the population for taste purposes. Fungi, seaweeds, and algae are also interesting sources of natural additives. These natural compounds have been around for some time, but in recent years they have gained more interest from 
the food industry for direct application or in synergy with other natural or chemical additives. Among the many effects, the most studied natural additive activities are their antimicrobial and antioxidant powers (Rasooli 2007; Tiwari and others 2009; Brewer 2011; Pillai and Ramaswamy 2012).

\section{Natural antimicrobials}

Natural antimicrobials that can be added to food are mainly terpenes, peptides, polysaccharides, and phenolic compounds, among others with less expression. Examples of terpenes and their relatives include carvacrol, thymol, and menthol. Carvacrol is a monoterpenoid phenol, present in large quantities in oregano with great antimicrobial (Escherichia coli, Bacillus cereus, and Staphylococcus) and antifungal activities, even at low concentrations (Ultee and Smid 2001; Ultee and others, 2002; Nostro and others, 2006; Xu and others, 2008). Carvacrol can act in synergy with cinnamaldehyde and nisin potentiating its effects. This compound has also been described as antimutagenic in the Ames Salmonella/microsomal test $(0.5 \mu \mathrm{L} / \mathrm{plate})$ (Ipek and others 2005). Finally, positive results were obtained from the microencapsulation of carvacrol, allowing a slower spreading of its antimicrobial activity, therefore potentiating its use (Periago and Moezelaar 2001; Liolios and others 2009; Guarda and others 2011; Ye and others 2013). Thymol is an isomer of carvacrol and it displays the same antibacterial and fungicidal activity (Ahmad and others 2009; Anderson and others 2009). Eugenol, a polyphenol used in various food and pharmacological applications is effective against the carcinogenic aflatoxin B1 (300 ppm) produced by Aspergillus flavus, as well as an inhibitor of other species of Aspergillus in vitro (150 ppm) (Pillai and Ramaswamy 2011; Komala and others 2012). Natural polysaccharides that are already used as food additives have positive effects on health with no reported toxicity. Chitosan and its derivatives, chitooligosaccharides, 
extracted from the shells of crustaceans, are used in the food and pharmaceutical industries for their beneficial effects, namely hypocholesterolemic, antimicrobial, immunity enhancing, antitumor, anticancer, anti-inflammatory, calcium-absorbing improvement, and antioxidant power among others (Xia and others 2011). It is used as a food additive, but it also takes part in the manufacture of antimicrobial biofilms and can be used combined with other molecules, like xylan and glucose (Kanatt and others 2008; Dutta and others 2009; Kong and others 2010; Li and others 2011). Nisin, a peptide comprised of 34 amino acids has long been used in the food industry due to its excellent antibacterial properties, namely against Clostridium perfringens, Clostridium sporogenes and others (Jamura and others 2005; He and Chen 2006; Udompijitkul and others 2012). It has been used with good results in meat, Galotyri cheese, and other foodstuffs. This natural compound has also reported toxicological effects on mice and has been described as arresting the progression of squamous cell carcinoma in human cell lines (Joo and others 2012). The synergic effects of nisin, as well as its encapsulation viability, have been investigated with apparent success (Hagiwara and others 2010; Malheiros and others 2012; Boualem and others 2013; Kallinteri and others 2013). Many other types of naturally occurring molecules are effective against food microbial contaminants, namely peptides, which are also known as bacteriocins. Bacteriocins should not be confused with antibiotics, their use is strictly for food, while antibiotics are for clinical/medical use. These molecules have no reported toxicity or secondary effects, unlike antibiotics (Cleveland and others 2001).

\section{Natural antioxidants}

Antioxidants present in plants, algae, and mushrooms are excellent natural additives to be added to foodstuffs for their ion or hydrogen donating, metal chelating, and chain breaking capabilities. Among others, the most antioxidant natural molecules are 
vitamins, polyphenols, and carotenoids. These groups of molecules, although being antioxidants can also exhibit additional properties (Ferreira and others 2009; Shahidi and Zhong 2010; Brewer 2011; Carocho and Ferreira 2013a).

The main vitamins with antioxidant potential already in use as food additives are vitamin $\mathrm{C}$ (ascorbic acid) and vitamin $\mathrm{E}$ (tocopherols). Vitamin $\mathrm{C}$ is an essential vitamin for humans that can only be acquired through diet (Davey and others 2000). This molecule is an effective scavenger of the superoxide radical anion, hydrogen peroxide, hydroxyl radical, singlet oxygen, and reactive nitrogen oxide, avoiding oxidative stress in the human body. In the food industry, ascorbic acid is one of the most used antioxidants, being used in the meat, beverage, fish, and bread industries, among others. By absorbing oxygen in the food, and oxidizing itself to dehydroascorbic acid, the available oxygen is reduced, therefore preserving the food. Apart from this antioxidant mechanism, ascorbic acid also acts as an antibrowning agent by reconverting quinones back to the phenolic form and avoiding flavor deterioration in beverages (Davey and others 2000; Carocho and Ferreira 2013a). Vitamin E is composed of 4 isoforms $(\alpha-$ tocopherol, $\beta$-tocopherol, $\gamma$-tocopherol and $\delta$-tocopherol) and 4 tocotrienols $(\alpha-$ tocotrienol, $\beta$-tocotrienol, $\gamma$-tocotrienol, and $\delta$-tocotrienol) (Hussain and others 2013). This vitamin exerts its activity especially against lipid peroxidation and rancidification by donating its phenolic hydrogen to the peroxyl radicals forming tocopheroxyl radicals that, despite also being radicals, are unreactive and unable to continue the oxidative chain reaction. Both these vitamins can work in synergism with the regeneration of vitamin $\mathrm{E}$ through vitamin $\mathrm{C}$ from the tocopheroxyl radical to an intermediate, reinstating once again its antioxidant potential. This is why they are usually employed together to extend shelf-life of foodstuffs (Carocho and Ferreira 2013a; Hussain and others 2013). Polyphenols, secondary metabolites, of plants are also excellent 
antioxidants. Among their various effects (antimicrobial, antimutagenic, anticancer, antitumor, anti-inflammatory), they also scavenge radicals, chelate metals, quench oxygen atoms, and can act as ion or hydrogen donors. The 8000 described polyphenols are divided into 8 groups: hydroxybenzoic acids, hydroxycinnamic acids, coumarins, lignans, chalcones, flavonoids, lignins and xanthones. Some polyphenols exhibit good antioxidant activity as pure compounds incorporated in foodstuffs, while others depend on synergism to carry out the protective effects. This is a drawback and at the same time an opportunity for the industry. For one, there is an imposing demand to get to the compound that exerts the effect, but at the same time synergisms can be research opportunities, which could be beneficial for the food industry (Carocho and Ferreira 2013a; Carocho and Ferreira 2013b). Polyphenols have been used as antioxidants in the fish and meat industries by dipping carcasses into polyphenolic extracts, allowing oxidation and bacterial contamination to be delayed (Fan and others 2008; Kumudavally and others 2008; Maqsood and others 2013). Other approaches have been tested with success, by incorporating natural extracts rich in polyphenols or pure compounds into food, and therefore avoiding rancidity, spoilage, and bacterial colony formation for a longer period of time when compared to the controls (Yao and others 2004; Serra and others 2008; Day and others 2009; Bansal and others 2013).

\section{Carotenoids}

Another important group of compounds are the carotenoids, defined as the pigments of nature. They occur in many colors, from red to yellow, and derive from the secondary metabolism in plants, bacteria, fungi, and algae. Some of the most important carotenoids are $\alpha$-carotene, $\beta$-carotene, and lycopene. The carotenoids have been used in the past, are still used presently as food colorants, and are approved for those purposes (Hendry and Houghton 1996; Nguyen and Schwartz 1998; Watson 2002; Nelis 
and Leenheer 2008). Recently, their antioxidant activity has been regarded as an added value when they are incorporated in food, and adding to the fact that they do not pose a toxicological threat, it makes them excellent natural food additives. $\beta$-Carotene, the precursor of vitamin A, has successfully been added to different foods, especially functional and nutraceutic beverages, and its usage for this purpose is estimated to increase in the future. Lycopene, one of the major constituents of tomatoes, has been successfully added to minced meat, increasing its storage stability, adding a natural taste, improving the color, and indicating health benefits (Østerlie and Lerfall 2005). Taking into account that there are more than 600 different carotenoids known, there is a high probability that many of them can display beneficial health effects (Branen and others 2001; Lerner and Lerner 2011).

\section{Essential oils}

Essential oils are hydrophobic liquids obtained by hydrodistillation or Likens-Nickerson extraction of plant parts containing terpenes and phenolic compounds. The health benefits of these oils are well-documented since the time their activities were first discovered. Essential oils are antioxidants, fungicidal, and bactericidal against Listeria, Staphylococcus, and other genera, improve the shelf-life of perishable foods, and delay spoilage. For some applications their effects are potentiated by synergisms established with bacteriocins or even food constituents. The only downside of essential oils is their potential toxicity to humans, even at low concentrations, and despite the extensive research on them, further and more meticulous assays should be carried out to determine the real effects of these oils in the human body and to determine an ADI (Smith-Palmer and others 2001; Holley and Patel 2005; Rasooli 2007; Sacchetti and others 2005; Kanatt and others 2008; Kumar and others 2008; Gutierrez and others 2009; Nguefack 
and others 2009; Tajkarimi and others 2010; Lv and others 2011; Tyagi and Malic 2011; Turgis and others 2012).

Although the natural additives are beneficial as antimicrobials and antioxidants, some of them have drawbacks; in some cases the amount needed for inhibition of certain contaminants is higher than the amount needed when using synthetic chemical compounds. On the other hand, certain natural additives can add flavor to food, which can be a disadvantage for some of the effective chemical antimicrobials. Furthermore, some polyphenols can interact with proteins, carbohydrates, minerals, and vitamins, which might not prove to be beneficial or not exert the desired functions in foods. This needs further research (Lule and Xia 2005; Rasooli 2007).

\section{PROBLEMS, OPORTUNITIES AND FUTURE PERSPECTIVES}

It is estimated that the world's population will reach 8 billion by 2025 . This increase represents a challenge for the whole planet. Larger amounts of food must be produced to feed the increasing population, especially in underdeveloped countries. Technology improves all of the food processing stages, in particular the technologies contributing to food preservation, such as mild-heat-processing, modified atmosphere packaging, vacuum packaging, and refrigeration. New technologies like pulsed-light, high pressure, pulsed-electric, and magnetic fields, high-pressure processing, ionizing radiation, and ultraviolet radiation are actively being investigated in order to overcome their specific limitations and costs. Although these technologies are effective in reducing the number of additives in food, these molecules cannot be completely removed in the highdemanding worldwide food market. Therefore, it is imperative to find viable solutions for the future food concern (Lado and Yousef 2002; Tajkarimi and others 2010). 
In the 21 st century, where information has no boundaries and can reach a high number of people in seconds, and with the literacy of citizens rising, the demand for clarification regarding food additives has grown considerably. In an inverse proportion, the trust in food safety agencies has declined, and citizens around the world are worried about the food they consume. Various surveys indicate that some consumers are alarmed about food additives and do not feel well informed regarding their role in food. The population does not know the difference between some groups of additives and is prone to be misled by marketing efforts that request "clean labels", which are labels that do not display names of compounds that resemble chemical or synthetic ones. Another troubling fact is the consumption of highly transformed food that is growing considerably due to the exodus of populations from the countryside to large cities and a way of life away from self-sufficiency. Home-preparation of food is now substituted by the "ready to consume" meal that just needs to be heated. The high consumption of this type of food imposes 2 important reflections. For one, the need for better, safer, and multipurpose additives (rather than adding various different ones to the same foodstuff) and, on the other hand, the need to educate the population to on the composition of natural and highly processed foods, as well as balanced and unbalanced diets and the necessity of additives. So far, only the schooled fraction of the population of developed countries has become aware of these issues. Some advocates even plead for a shift to a reduced consumption of highly processed foods (Shim and others 2010; Varela and Fiszman 2013).

The concern about misinformation regarding food additives is also fueled by the blurred separation between natural and synthetic additives. Today, additives are usually added to repair damage to food during its harvesting, storage, and processing, by correcting the final foods' colors, texture, moisture, flavors. The actual truth is that, in the global 
food market, of 30 billion dollars, $40 \%$ of all additives are used to keep the taste of the food products, $30 \%$ employed for texture, $5 \%$ for food appearance, $20 \%$ for aiding the processing phase, and 5\% is added to fight bacterial spoilage and rapid deterioration.

The core studies regarding food additive safety in the USA have been unaltered for 40 years, it is now time to review these protocols and prepare new ones, incorporating new technologies, new knowledge, and leaving space for wider, transversal, and undoubted debates within the scientific community and by stakeholders. The EU in its review of food additives until 2020, is taking these premises into account to gather a transversal understanding of both the scientific community and legislators. Although difficult, a unique European law regarding food additives could be the best solution to bring confidence to the legislating bodies as well as safety to the food that is consumed by the more than 500 million people living within the EU. This mission is quite challenging due to the difficulty to obtain concrete, sound, and irrefutable results regarding human exposure to additives when taking into account the different diets, lifestyles, ages, and genetic predispositions of citizens (Bateman and others 2004; Connolly and others 2010; Mepham 2011; Lofstedt 2013).

The future of food additives is of grave importance for mankind, it is related to the wellbeing of the entire human population. Food additives will definitely change throughout the next decades, either tending to natural extracts that need to be thoroughly studied for interactions or to the synthetic chemical ones that will continue to scare the consumers. Future technologies regarding food additives have been studied and aim to reduce impact on health, manufacture costs, and controversy, having also the minimum effect on the final appearance of food. Nanotechnology, which is already widely used for different purposes is also being applied to food and to packaging, encapsulating the additives, allowing for controlled release, increase in stability, and reduction of impact 
in the final product. In a near future, it is expected that these nanostructures, present within the food or in the package, detect decay or contamination, and only then start the release of specific antioxidants or antimicrobials (Appendini and Hotchkiss 2002; Duncan 2011; Cushen and others 2012; Coles and Frewer 2013; Sung and others 2013).

Filamentous fungi are already used to produce several natural compounds with color. These could be used as food colorants, substituting their chemical counterparts. This technology will be used in the near future for the other classes of food additives, taking advantage of the extraordinary capacity of fungi and bacteria to produce specific compounds (Dufossé and others 2014). Genetic biomarkers are being studied in order to early detect potential allergic reactions to food additives, and vaccines are being developed to be administered to additive susceptible individuals, allowing potential allergens to be added to food or added in a higher concentration (Watson 2002). Among all the technologies used for food additives, recombinant DNA will be the one with the greatest effect. It is already used in bioprocessing to develop additives and could even reduce the need for common additives. Some plants, produced through recombinant DNA displayed extended shelf-life and a higher nutritional value (Branen and other 2001).

The reception of these new technologies will also depend on how research is conducted in these fields and also how governing bodies legislate towards them, leading to their increasing use or eventual demise. These agencies should harmonize legislation and publish unique and easily accessible guidelines that should be applied worldwide. These guidelines should be approved by the scientific community which can provide important information and input, but also by food companies for economic feasibility. In a future where consumers will be highly aware of the ingredients of their food, legislation that is well prepared, well reviewed, intended to provide minimum risk, and have worldwide 
applicability, will reduce doubt and, distrust, and hopefully keep the market operating efficiently for a better future.

\section{CONCLUSIONS}

Food additives have changed since they were invented and widely used over the past century. Today, food additives ensure that food can be delivered around the world without losses in an ever-growing competitive market. Their role is becoming more and more important with the increase in consumption of highly processed foods due to changing lifestyles of modern world citizens. Despite the visible improvements in legislation and the production of safer additives, many issues still remain unsolved, leading to increasing controversy and constant demand for better ones. The most obvious cases include the prohibition of some additives in EU, which are used in the USA, and others that are banned in the USA and added to food in the EU. Although technologies will continue to develop and reduce the need for additives, while they are still necessary, taking into consideration the habits of consumers, it is expectable that natural additives will gain even more notoriety when compared to chemical ones. This could be due to their various beneficial effects on health, along with antimicrobial, antioxidant and other effects. The great number of compounds in nature that still remain unknown, the power of natural extracts and the synergisms with other compounds represent unlimited sources of new compounds with new possibilities. Today, natural additives don't answer all the doubts and issues, being unwise to use them as an immediate alternative to chemical additives due to the impact on economies and health. Careful studies regarding natural additives must be carried out to not make them a source of even more controversy. What should occur is a soft transition into the natural 
additives with a simultaneous reduction of additives altogether, relying on new technologies to carry out the same effects. There is no timeframe for this to happen, but it will surely take place, and there are 4 forces that will be legislators, scientists, commercial enterprises, and ultimately, consumers.

\section{ACKNOWLEDGEMENTS}

The authors are grateful to Proder $\mathrm{n}^{\mathrm{0}} 46577$ PlantLact for financial support of this work, to Fundação para a Ciência e a Tecnologia (FCT, Portugal) and COMPETE/QREN/EU for CIMO strategic project PEst-OE/AGR/UI0690/2011 and LSRE strategic project PEst-C/EQB/LA0020/2011. The authors also state that they do not have any conflicts of interest.

\section{REFERENCES}

Abhilash M, Paul MVS, Varghese MV, Nair RH. 2011. Effect of long-term intake of aspartame on antioxidant defense status in liver. Food Chem Toxicol 49:1203-7.

Abou-Donia MB, El-Masry EM, Abdel-Rahman AA, McLendon, R, Shiffman S. 2008. Splenda alters gut microflora and increases intestinal P-glycoprotein and cytochrome P-450 in male rats. J Toxicol Environ Health A 71:1415-29.

Abramsson-Zetterberg L, Ilbäck N. 2013. The synthetic food colouring agent allura red $\mathrm{AC}(\mathrm{E} 129)$ is not genotoxic in a flow cytometry-based micronucleus assay in vivo. Food Chem Toxicol 59:86-9.

Adams TB, Cohen SM, Doull J, Feron VJ, Goodman JI, Marnett LJ, Munro IC, Portoghese PS, Smith RL, Waddell WJ, Wagner BM. 2005. The FEMA GRAS 
assessment of benzyl derivatives used as flavor ingredients. Food Chem Toxicol 43:1207-40.

Ahmad A, Khan A, Akhtar F, Yousuf S, Xess I, Khan LA, Manzoor N. 2011. Fungicidal activity of thymol and carvacrol by disrupting ergosterol biosynthesis and membrane integrity against Candida. Eur J Clin Microbiol Infect Dis 30:4150.

Akhtar M, Dickinson E, Mazoyer J, Langendorff V. 2002. Emulsion stabilizing properties of depolymerisation pectin. Food Hydrocolloids 16:249-56.

Alger HM, Maffini MV, Kulkarni NR, Bongard ED, Nelter T. 2013. Perspectives on how FDA assesses exposure to food additives when evaluating their safety: Workshop proceedings. Compr Rev Food Sci Food Safety 12:90-119.

Ali RAM, Suzuki T. 2012. Detection of genotoxicity of phenolic antioxidants, butylated hydroxyanisole and tert-butylhydroquinone in multiple mouse organs by the alkaline comet assay. J Am Sci 8:722-27.

Amadasi A, Mozzarelli A, Meda C, Maggi A, Cozzini P. 2009. Identification of xenoestrogens in food additives by an integrated in silico and in vitro approach. Chem Res Toxicol 22:52-63.

Amin KA, Hameid II H A, Elsttar AHA. 2010. Effect of food azo dyes tartrazine and carmoisine on biochemical parameters related to renal, hepatic function and oxidative stress biomarkers in young male rats. Food Chem Toxicol 48:2994-99.

Anderson RC, Krueger NA, Byrd JA, Harvey RB, Callaway TR, Edrington T, Nisbet DJ 2009. Effects of thymol and diphenyliodonium chloride against Campylobacter spp. during pure and mixed culture in vitro. J Appl Microbiol 107:1258-68. 
Anton SD, Martin CK, Han H, Coulon S, Cefalu WT, Geiselman P, Williamson DA. Effects of stevia, aspartame, and sucrose on food intake satiety and postprandial glucose and insulin levels. Appetite 55:37-43.

Appendini P, Hotchkiss JH. 2002. Review of antimicrobial food packaging. Innov Food Sci Emerging Tec 3:113-26.

Arvin M, Dehghan G, Hosseinpourfeizi MA, Moosavi-Movagedi AA. 2013. Spectroscopic and electrochemical studies on the interaction of carmoisine food additive with native calf thymus DNA. Spectrocsc Lett 46:250-6.

Ashok I, Sheeladevi R, Wankhar D. 2013. Effect of long-term aspartame (artificial sweetener) on anxiety, locomotor activity and emotionality behaviour in Wistar albino rats. Biomed Prev Nutr DOI: 10.1016/j.bionut.2013.04.002 (accessed October 2013).

Aubert N, Ameller T, Legrand J. 2012. Systemic exposure to parabens: Pharmacokinetics, tissue distribution, excretion balance and plasma metabolites of $\left[{ }^{14} \mathrm{C}\right]$-methyl-, propyl- and butylparaben in rats after oral, topical or subcutaneous administration. Food Chem Toxicol 50:445-54.

Axon A, May FEB, Gaughan LE, Williams FM, Blain PG. Wright MC. 2012. Tartrazine and sunset yellow are xenoestrogens in a new screening assay to identify modulators of human oestrogen receptor transcriptional activity. Toxicol 298:40-51.

Aziz AHA, Shouman SA, Attia AS, Saad SF. 1997. A study on the reproductive toxicity of erythrosine in male mice. Pharmacol Res 35:457-62.

Baird IM, Shephard NW, Merritt RJ, Hildick-Smith G. 2000. Repeated dose study of sucralose tolerance in human subjects. Food Chem Toxicol 38:123-9. 
Bandyopadhyay A, Ghoshal S, Mukherjee A. 2008. Genotoxicity testing of low-calorie sweeteners: aspartame, acesulfame-K, and saccharin. Drug Chem Toxicol 31:44757.

Bansal S, Choudhary S, Sharma M, Kumar SS, Lohan S, Bhardwaj V, Syan N, Jyoti S. 2013. Tea: A native source of antimicrobial agents. Food Res Int 53:568-84.

Bateman B, Warner JO, Hutchinson E, Dean T, Rowlandson P, Gant C, Frundy J, Fitzgerald C, Stevenson J. 2004. The effects of a double-blind, placebocontrolled, artificial food colourings and benzoate preservative challenge on hyperactivity in a general population sample of preschool children. Arch Dis Child 89:506-11.

Becerril R, Manso S, Nerin C, Gómez-Lus R. 2013. Antimicrobial activity of Lauroyl arginate ethyl (LAE), against selected food-borne bacteria. Food Control 32:4048.

Beezhold BL, Johnston CS, Nochta, KA. 2012. Sodium benzoate-rich beverage consumption is associated with increase reporting of ADHD symptoms in college students: A pilot investigation. $\mathrm{J}$ Attention Disor DOI: 10.1177/1087054712443156 (accessed October 2013).

Belsito D, Bickers D, Bruze M, Calow P, Dagli ML, Fryer AD, Greim H, Miyachi Y, Sipes IG. 2012. A toxicological and dermatological assessment of aryl alkyl alcohols when used as fragrance ingredients. Food Chem Toxicol 50:552-99.

Binstok G, Campos C, Varela O, Gerschenson LN. 1998. Sorbate-nitrite reactions in meat products. Food Res Int 31:581-5.

Błaszczyk A, Augustyniak A, Skolimowski J. 2013. Ethoxyquin: An antioxidant used in animal feed. Int J Food Sci 2013:1-12. 
Błaszczyk A, Osiecka R, Skolimowski J. 2003. Induction of chromosome aberrations in cultured human lymphocytes treated with ethoxyquin. Mutat Res 542:117-28.

Bonaccorsi G, Perico A, Colzi A, Bavazzano P, Giusto MD, Lamberti I, Martino G, Lorini C. 2012. Benzene in soft drinks: A study in Florence (Italy). Ig Sanita Pubbl 68:523-32.

Botterweck AAM, Verhagen H, Goldbohm RA, Kleinjans J, Brandt PA. 2000. Intake of butylated hydroxyanisole and butylated hydroxytoluene and stomach cancer risk: Results from analyses in the Netherlands cohort study. Food Chem Toxicol 38:599-605.

Boualem K, Subirade M, Desjardins Y, Saucier L. 2013. Development of an encapsulation system for the protection and controlled release of antimicrobial nisin at meat cooking temperature. J Food Res 2:36-45.

Bourtoom T. 2008. Edible films and coatings: Characteristics and properties. Int Food Res J 15:237-248.

Bouyer E, Mekhloufi G, Rosilio V, Grossiord J, Agnely F. 2012. Proteins, polysaccharides, and their complexes used as stabilizers for emulsions: Alternatives to synthetic surfactants in the pharmaceutical field? Int J Pharm 436:359-78.

Branen AL, Davidson PM, Salminen S, Thorngate J. 2001. Food additives. Taylor \& Francis. New York.

Bray GA, Nielsen SJ, Popkin BM. 2004. Consumption of high-fructose corn syrup in beverages may play a role in the epidemic of obesity. Am J Clin Nutr 79:537-43.

Brewer MS. 2011. Natural antioxidants: Sources, compounds, mechanisms of action, and potential applications. Comp Rev Food Sci Food Safety 10:221-47. 
Brown RJ, Banate MA, Rother KI. 2010. Artificial sweeteners: A systematic review of metabolic effects in youth. Int J Pediatr Obes 5:305-12.

Bronzwaer S. 2008. EFSA scientific forum "from safe food to healthy diets". EU risk assessment-Past, present and future. Trends Food Sci Technol 19:S2-S8.

Brul S, Coote P. 1999. Preservative agents in foods: Mode of action and microbial resistance mechanisms. Int J Food Microbiol 50:1-17.

Brusick D, Borzelleca JF, Gallo M, Williams G, Killie J, Hayes AW, Pi-Sunyer FX, Williams C, Burks W. 2009. Expert panel report on a study of Splenda in male rats. Regul Toxicol Pharma 55:6-12.

Brusick D, Grotz VL, Slesinski R, Kruger, CL, Hayes AW. 2010. The absence of genotoxicity of sucralose. Food Chem Toxicol 48:3067-72.

Cakir R, Cagri-Mehmetoglu. 2013. Sorbic and benzoic acid in non-preservative-added food products in Turkey. Food Addit Contam 6:47-54.

Calvo C, Salvador A. 2000. Use of natural colorants in food gels. Influence of composition of gels on their colour and study of their stability during storage. Food Hydrocolloid 14:439-43.

Cammack R, Joannou CL, Cui X, Martinez CT, Maraj SR, Hughes MN. 1999. Nitrite and nitrosyl compounds on food preservation. Biochim Biophys Acta 1411:47588.

Cantarelli MA, Pellerano RG, Marchevsky EJ, Camiña JM 2009. Simultaneous determination of aspartame and acesulfame- $\mathrm{K}$ by molecular absorption spectrophotometry using multivariate calibration and validation by highperformance liquid chromatography. Food Chem 115:1128-32. 
Carakostas MC, Curry LL, Boileau AC, Brusick DJ. 2008. Overview: The history, technical function and safety of rebaudioside A, a naturally occurring steviol glycoside, for use in food and beverages. Food Chem Toxicol 46:S1-S10.

Carocho M, Ferreira ICFR 2013a. A review on antioxidants, prooxidants and related controversy: Natural and synthetic compounds, screening and analysis methodologies and future perspectives. Food Chem Toxicol 51:15-25.

Carocho M, Ferreira ICFR 2013b. The role of phenolics compounds in the fight against cancer - A review. Anticancer Agents Med Chem 13:1236-58.

Castelain F, Castelain M. 2012. Parabens: a real hazard or a scare story? Eur J Dermatol 22:723-27.

Ceyhan BM, Gultekin F, Doguc DK, Kulac E. 2013. Effects of maternally exposed coloring food additives in receptor expressions related to learning and memory rats. Food Chem Toxicol 56:145-8.

Chan TYK. 2011. Vegetable-borne nitrate and nitrite and the risk of methaemoglobinaemia. Toxicol Lett 200:107-8.

Chequer FMD, Venâncio VP, Bianchi MLP, Antunes LMG. 2012. Genotoxic and mutagenic effects of erythrosine B, a xanthene food dye, on HepG2 cells. Food Chem Toxicol 50:3447-51.

CFR, Code of Federal Regulations. Title 21, Food and Drugs. Volume 3. Available from: http://www.extension.iastate.edu/foodsafety/downloads/21cfr170-3.pdf.

Chen YQ, Ni YN. 2009. Simultaneous spectrophotometric determination of four preservatives in foodstuffs by multivariate calibration and artificial neural networks. Chinese Chem Lett 20:615-9. 
Chen C, Lin W, Kuo C, Lu F. 2011. Role of redox signalling regulation in the propyl gallate-induced apoptosis of human leukemia cells. Food Chem Toxicol 49:494501.

Cheng H, Friis A, Leth T. 2010. Partition of selected food preservatives in fish oilwater systems. Food Chem 122:60-4.

Chow CK, Hong CB. 2002. Dietary vitamin E and selenium and toxicity of nitrite and nitrate. Toxicol 180:195-207.

Chudgar, RJ, Oakes J. 2003. Dyes, azo. Kirk-Othmer encyclopedia of chemical technology. John Wiley \& Sons, West Sussex, UK.

Chung K. 2000. Mutagenicity and carcinogenicity of aromatic amines metabolically produced from azo dyes. Environ Carcino Ecotox Revs C 18:51-74.

Ciardi C, Jenny M, Tschoner A, Ueberall F, Patsch J, Pedrini M, Ebenbichler C, Fuchs D. 2012. Food additives such as sodium sulphite, sodium benzoate and curcumin inhibit leptin release in lipopolysaccharide-treated murine adipocytes in vitro. Brit J Nutr 107:826-33.

Cleveland J, Montville TJ, Nes IF, Chikindas ML. 2001. Bacteriocins: Safe, natural antimicrobials for food preservation. Int J Food Microbiol 71:1-20.

Codex Alimentarius. Accessed August 2013. Available from: www.codexalimentarius.net/gsfaonline/docs/CXS_192e.pdf.

Cohen-Addad N, Chatterjee M, Bekersky I, Blumenthal HP. 1986. In utero-exposure to saccharin: A threat? Cancer Lett 32:151-4.

Coles D, Frewer LJ. 2013. Nanotechnology applied to European food production-A review of ethical and regulatory issues. Trend Food Sci Tec 34:32-43. 
Connolly A, Hearty Á, Nugent A, McKevitt A, Boylan E, Flynn A, Gibney MJ. 2010. Pattern of intake of food additives associated with hyperactivity in Irish children and teenagers. Food Addit Contam A 27:447-56.

Council Regulation (EC) 1333/2008 of 16 December 2008 on food additives. 2008. OJ L354/16.

Council Regulation (EC) 1129/2011 of 11 November 2011 on amending Annex II to Regulation (EC) No 1333/2008 of the European Parliament and of the Council by establishing a Union list of food additives.

Cressey P, Jones S. 2009. Levels of preservatives (sulphite, sorbate and benzoate) in New Zealand food and estimated dietary exposure. Food Addit Contam 26:60413.

Cushen M, Kerry J, Morris M, Cruz-Romero M, Cummins E. 2012. Nanotechnologies in the food industry-Recent developments, risks and regulation. Trend Food Sci Tec 24:30-46.

Darbre PD, Aljarrah A, Miller WR, Coldham NG, Sauer MJ, Pope GS. 2004. Concentrations of parabens in human breast tumours. J Appl Toxicol 24:5-13.

Datta S, Mahapatra N, Halder M. 2013. pH-insensitive electrostatic interaction of carmoisine with two serum proteins: A possible caution on its uses in food and pharmaceutical industry. J Photoch Photobio B 124:50-62.

Davey MW, Montagu MV, Inzé D, Sanmartin M, Kanellis A, Smirnoff N, Benzie IJJ, Strain JJ, Favell D, Fletcher J. 2000. Plant L-ascorbic acid: Chemistry, function, metabolism, bioavailability and effects of processing. J Sci Food Agric 80:825-60.

Day L, Seymour RB, Pitts KF, Konczak I, Lundin L. 2009. Incorporation of functional ingredients into foods. Trends Food Sci Tech 20:388-95. 
Debeaufort F, Quezada-Gallo J, Voilley A. 1998. Edible films and coatings: Tomorrow's packagings: A review. Crit Rev Food Sci Nutr 38:299-313.

Delgado-Vargas F, Jiménez AR, Paredes-López O. 2000. Natural pigments: Carotenoids, anthocyanins, and betalains - characteristics, biosynthesis, processing, and stability. Crit Rev Food Sci Nutr 40:173-289.

Dengate S, Ruben A. 2002. Controlled trial of cumulative behavioural effects of a common bread preservative. J Paediatr Child Health 38:373-6.

Dorato MA, Engelhardt JA. 2005. The no-observable-adverse-effect level in drug safety evaluations: Use, issues, and definition(s). Regul Toxicol Pharmacol 42:265-74.

Downham A, Collins P. 2000. Colouring our foods in the last and next millennium. Int J Food Sci Technol 35:5-22.

Dufossé L, Fouillaud M, Caro Y, Mapari SAS, Sutthiwong N. 2014. Filamentous fungi are large-scale producers of pigments and colorants for the food industry. Curr Opin Biotechnol 26:56-61.

Duncan TV. 2011. Applications of nanotechnology in food packaging and food safety: Barrier materials, antimicrobials and sensors. J Colloid Interf Sci 363:1-24.

Dutta PK, Tripathi S, Mehrotra GK, Dutta J. 2009. Perspectives for chitosan based antimicrobial films in food applications. Food Chem 114:1173-82.

Dybing E. 2002. Development and implementation of the IPCS conceptual framework for evaluating mode of action of chemical carcinogens. Toxicol 181:121-5.

EAFUS, Food and Drug Administration, Everything Added to Food in the United States. Accessed $\quad$ September 2013. Available from: http://www.accessdata.fda.gov/scripts/fen/fcnnavigation.cfm?rpt=eafuslisting.

EFSA 2000. Re-evaluation of acesulfame K with reference to the previous SCF opinion of 1991. Available from: http://ec.europa.eu/food/fs/sc/scf/out52_en.pdf. 
EFSA 2004. Opinion of the scientific panel on food additives, flavourings, processing aids and materials in contact with food on a request for the commission related to tertiary-Butylhydroquinone (TBHQ) Available from: http://www.efsa.europa.eu/en/efsajournal/doc/84.pdf.

EFSA 2008. Regulation (EC) No 1333/2008 of the European Parliament and of the council of 16 December 2008 on food additives. Available from: http://eurlex.europa.eu/LexUriServ/LexUriServ.do?uri=OJ:L:2008:354:0016:0033:en:PDF.

EFSA 2010a. Scientific Opinion on the safety of steviol glycosides for the proposed uses as food additive. EFSA J 8(4);1537. DOI: 10.2903/j.efsa.2010.1537. Available from: http://www.efsa.europa.eu/en/efsajournal/doc/1537.pdf.

EFSA 2010b. Scientific opinion on the re-evaluation of Green S (E142) as a food additive. EFSA J 8(11);1851. DOI: 10.2903/j.efsa.2010.1851. Available from: http://www.efsa.europa.eu/en/efsajournal/doc/1851.pdf

EFSA 2011. Panel on food additives and nutrient sources added to food (ANS); Scientific opinion on the reevaluation of butylated hydroxyanisole-BHA (E 320) as a food additive. EFSA J 9(10);2392. DOI: 10.2903/j.efsa.2011.2392. Available from: http://www.efsa.europa.eu/en/efsajournal/doc/2392.pdf.

EFSA 2012a. Panel on food additives and nutrient sources added to food (ANS); Scientific opinion on the reevaluation of butylated hydroxytoluene BHT (E 321) as a food additive. EFSA J 10(3);2588. DOI: 10.2903/j.efsa.2012.2588. Available from: http://www.efsa.europa.eu/en/efsajournal/doc/2588.pdf.

EFSA 2012b. Panel on food additives and nutrient sources added to food (ANS); Guidance for submission for food additive evaluations. EFSA J 2012; 10(7);2760. Available from: http://www.efsa.europa.eu/efsajournal. 
EFSA 2013a, Reasoned opinion on the review of the existing maximum residue levels (MRLs) for ethoxyquin according to Article 12 of Regulation (EC) No 396/20051; EFSA J 2013; 11(5);3231. Available from: http://www.efsa.europa.eu/en/efsajournal/doc/3231.pdf

EFSA 2013b, Press release. Aspartame: EFSA consults on its first full risk assessment. Available from: http://www.efsa.europa.eu/en/press/news/130108.htm.

Elsabee MZ, Abdou ES. Chitosan based edible films and coatings: A review. Mater Sci Eng C 33:1819-41.

Ema M, Hara H, Matsumoto M, Hirata-Koizumi M, Hirose A, Kamata E. 2008. Evaluation of developmental neurotoxicity of polysorbate 80 in rats. Reprod Toxicol 25:89-99.

Engin AB, Bukan N, Kurukahvecioglu O, Memis L, Engin A. 2011. Effect of butylated hydroxytoluene (E321) pretreatment versus L-arginine on liver injury after sublethal dose of endotoxin administration. Environ Toxicol Pharmacol 32:457-64.

Embuscado ME, Huber KC. 2009. Edible films and coatings for food applications. Springer New York, USA.

Eskandani, M, Hamishehkar H, Dolatabadi JEN. 2013. Cyto-genotoxicity study of polyoxyethylene (20) sorbitan monolaurate (Tween 20). DNA Cell Biol 32:498503.

Espitia PJP, Du W, Avena-Bustillos RJ, Soares NFF, McHugh TH. 2014. Edible films for pectin: Physical-mechanical and antimicrobial properties - A review. Food Hydrocolloid 35:287-96.

Eweka AO, Om'Iniabohs FAE. 2011. Histological studies of the effects of monosodium glutamate on the ovaries of adult Wistar rats. Ann Medical Health Sci Res 1:3744. 
Fan W, Chi Y, Zhang S. 2008. The use of tea polyphenol dip to extend the shelf life of silver carp (Hypophthalmicthys molitrix) during storage in ice. Food Chem 108:148-53.

FDA Redbook, Food and Drug Administration. Accessed September 2013. Available from:

http://www.fda.gov/Food/GuidanceRegulation/GuidanceDocumentsRegulatoryInf ormation/IngredientsAdditivesGRASPackaging/ucm2006826.htm.

Feijó FM, Ballard CR, Foletto KC, Batista BAM, Neves AM, Ribeiro MFM, Bertoluci MC. 2013. Sacharin and aspartame, compared with sucrose, induce greater weight gain in adult Wistar rats, at similar total caloric intake levels. Appetite 60:203-7.

Fennema OR. 1987. Food additives - an unending controversy. Am J Clin Nutr 46:2013.

Fennema OR. 1996. Food chemistry (Third edition). Marcel Dekker, New York.

Ferrand C, Marc F, Fritsch P, Cassand P, Blanquat GS. 2000. Mutagenicity and genotoxicity of sorbic acid-amine reaction products. Toxicol In Vitro 14:423-8.

Ferreira ICFR, Barros L, Abreu RM. 2009. Antioxidants in wild mushrooms. Curr Med Chem 16:1543-60.

Ferreira IMPLVO, Mendes E, Brito P, Ferreira MA. 2000. Simultaneous determination of benzoic and sorbic acids in quince jam by HPLC. Food Res Int 33:113-7.

Frazier RA, Inns EL, Dossi N, Ames JM, Nursten HE. 2000. Development of a capillary electrophoresis method for the simultaneous analysis of artificial sweeteners, preservatives and colours in soft drinks. J Chromatogr A 876:213-20.

Gao Y, Li C, Shen J, Yin H, An X, Jin H. 2011. Effect of food azo dye tartrazine on learning and memory functions in mice and rats, and the possible mechanisms involved. J Food Sci 76:125-29. 
García-Gavín J, Parente J, Goossens A. 2012. Allergic contact dermatitis caused by sodium metabisulfite: A challenging allergen. A case series and literature review. Contact Dermatitis 67:260-9.

García-Jiménez MC, Capitán-Vallvey LF. 2007. Simultaneous determination of antioxidants, preservatives and sweetener additives in food and cosmetics by flow- injection analysis coupled to a monolithic column. Anal Chim Acta 594:226-33.

Gaur S, Sorg T, Shukla V. 2003. Systemic absorption of FD\&C blue dye associated with patient mortality. Postgrad Med J 79:602-3.

Gibbs BF, Alli I, Mulligan C. 1996. Sweet and taste-modifying poteins: A review. Nutr Res 16:1619-30.

Giusti MM, Wrolstad RE. 2003. Acylated anthocyanins from edible sources and their applications in food systems. Biochem Eng J 14:217-225.

González M, Gallego M, Valcárel M. 1999. Gas chromatographic flow method for the preconcentration and simultaneous determination of antioxidant and preservative additives in fatty foods. J Chromatogr A 848:529-36.

Guarda A, Rubilar JF, Miltz J, Galotto MJ. 2011. The antimicrobial activity of microencapsulated thymol and carvacrol. Int J Food Microbiol 146:144-50.

Guilbert S, Gontard N, Gorris LGM. 1996. Prolongation of the shelf-life of perishable food products using biodegradable films and coatings. LWT Food Sci Technol 29:10-7.

Gultekin F, Doguc, DK, Husamettin V, Taysi E. 2013. The effects of food and food additives on behaviors. Int J Health Nutr 4:21-32. 
Gutierrez J, Barry-Ryan C, Bourke, P. 2009. Antimicrobial activity of plant essential oils using food model media: Efficacy, synergistic potential and interactions with food components. Food Microbiol 26:142-50.

Ha MS, Ha SD, Choi SH, Bae DH. 2013. Exposure assessment of synthetic colours approved in Korea. Food Addit Contam A 30:643-53.

Han J. 2013. Innovations in food packaging, $2^{\text {nd }}$ Edition. Academic Press, Elsevier, London, UK.

Han YH, Park WH. 2009. Propyl gallate inhibits the growth of HeLa cells via regulating intracellular GSH level. Food Chem Toxicol 47:2531-8.

Hagiwara A, Imai N, Nakashima H, Toda Y, Kawabe M, Furukawa F, DelvesBroughton J, Yasuhara K, Hayashi S. 2010. A 90-day toxicity of nisin A, an antimicrobial peptide derived from Lactococcus lactis subsp. lactis, in F344 rats. Food Chem Toxicol 48:2421-8.

Harvey PW, Everett, DJ. 2004. Significance of the detection of esters of $p$ hydroxybenzoic acid (parabens) in human breast tumours. J Appl Toxicol 24:1-4.

He L, Chen W. 2006. Synergistic activity of nisin with cell-free supernatant of Bacillus licheniformis ZJU12 against food-borne bacteria. Food Res Int 39:905-9.

He K, Du S, Xun P, Sharma S, Wang H, Zhai F, Popkin B. 2011. Consumption of monosodium glutamate on relation to incidence of overweight in Chinese adults: China Health and Nutrition Survey (CHNS). Am J Clin Nutr 93: 1328-36.

Hendry GAF, Houghton JD, 1996. Natural food colorants. Second edition. Blackie \& Professional, London UK.

Holley R, Patel D. 2005. Improvement in shelf-life and safety of perishable foods by plant essential oils and smoke antimicrobials. Food Microbiol 22:273-92. 
Hord NG, Tang Y, Bryan NS. 2009. Food sources of nitrates and nitrites: The physiologic context for potential health benefits. Am J Clin Nutr 90:1-10.

Hord NG. 2011. Dietary nitrates, nitrites, and cardiovascular disease. Curr Atheroscler Rep 13:484-92.

Hussain N, Irshad F, Jabeen Z, Shamsi IH, Li Z, Jiang L. 2013. Biosynthesis, structural, and functional attributes of tocopherol in plants; Past, present, and future perspectives. J Agri Food Chem 61:6137-49.

Ipek E, Zeytinoglu H, Okay S, Tuylu BA, Kurkcuoglu M, Baser KHC. 2005. Genotoxicity and antigenotoxicity of Origanum oil and carvacrol evaluated by the Ames Salmonella/microsomal test. Food Chem 93:551-6.

Isaac A, Livingstone C, Wain AJ, Compton RG, Davis J. 2006. Electroanalytical methods for the determination of sulfite in food and beverages. Trend Anal Chem 25:589-98.

Iturriaga L, Olabarrieta I, Marañón IM. 2012. Antimicrobial assays of natural extracts and their inhibitory effect against Listeria innocua and fish spoilage bacteria, after incorporation into biopolymer edible films. Int J Food Microbiol 158:58-64.

Iwata T, Kimura Y, Tsutsumi K, Furukawa Y, Kimura S. 1993. The effect of various phospholipids on plasma lipoproteins and liver lipids in hypercholesterolemic rats. J Nutr Sci Vitaminol 39:63-71.

Jacobi H, Eicke B, Wittie I. 1998. Strand break induction and enhanced cytotoxicity of propyl gallate in the presence of copper (II). Free Rad Biol Med 24:972-8.

Jamuna M, Babusha ST, Jeevaratnam K. 2005. Inhibitory efficacy of nisin and bacteriocins from Lactobacillus isolates against food spoilage and pathogenic oranisms in model and food systems. Food Microbiol 22:449-54. 
Jeong S, Kim B, Kang H, Ku H, Cho J. 2005. Efects of butylated hydroxyanisole on the development and functions of reproductive system in rats. Toxicol 208:49-62.

Joo NE, Ritchie K, Kamarajan P, Miao D, Kapila Y. 2012. Nisin, an apoptogenic bacteriocin and food preservative, attenuates HNSCC tumorigenesis via CHAC1. Cancer Medicine 1:295-305.

Jung R, Cojocel C, Müller W, Böttger D, Lück E. 1992. Evaluation of the genotoxic potential of sorbic acid and potassium sorbate. Food Chem Toxicol 30:1-7.

Kallinteri LD, Kostoula OK, Savvaidis IN. 2013. Efficacy of nisin and/or natamycin to improve the shelf-life of Galotyri cheese. Food Microbiol 36:176-81.

Kanatt SR, Chander R, Sharma A. 2008. Chitosan glucose complex - A novel food preservative. Food Chem 106:521-8.

Karstadt ML. 2006. Testing needed for acesulfame potassium, artificial sweetener. Environ Health Persp 114:516.

Komala VV, Ratnavathi C, Vijay, BS, Das IK. 2012. Inhibition of aflatoxin B1 production by an antifungal component, eugenol in stored sorghum grains. Food Control 23:139-46.

Kong M, Chen XG, Xing, Park HJ. 2010. Antimicrobial properties of chitosan and mode of action: A state of the art review. Int J Food Microbiol 144:51-63.

Koyama E, Kitazawa K, Ohori Y, Izawa O, Kakegawa K, Fujino A, Ui M. 2003. In vitro metabolism of the glucosidic sweeteners, stevia mixture and enzymatically modified stevia in human intestinal flora. Food Chem Toxicol 41:359-74.

Kroger M, Meister K, Kava R. 2006. Low-calorie sweeteners and other sugar substitutes: A review of the safety issues. Compr Rev Food Sci Food Safety 5:3547. 
Kumar A, Shukla R, Singh P, Prasad CS, Dubey NK. 2008. Assessment of Thymus vulgaris L. essential oil as safe botanical preservative against post-harvest fungal infestation of food commodities. Innov Food Sci Emerg Technol 9:575-80.

Kumudavally KV, Phanindrakumar HS, Tabassum A, Radhakrishna K, Bawa AS. 2008. Green tea-A potential preservative for extending the shelf life of fresh mutton at ambient temperature $\left(25 \pm 2{ }^{\circ} \mathrm{C}\right)$. Food Chem 107:426-33.

Lado B H, Yousef AE, 2002. Alternative food-preservation technologies: efficacy and mechanisms. Microbes Infect 4:433-40.

Lakshmi G, Buchwald P. 2013. The promiscuous protein binding ability of erythrosine B studied by metachromasy (metachromasia). J Mol Recognit 26:181-9.

Lau K, McLean WG, Williams DP, Howard CV. 2006. Synergistic interactions between commonly used food additives in a developmental neurotoxicity test. Toxicol Sci 90:178-87.

Leisenring W, Ryan L. 1992. Statistical properties of the NOAEL. Regul Toxicol Pharmacol 15: 161-171.

Leleu C, Bouitrop C, Bel B, Jeudy G, Vabres P, Collet E. 2013. Quinoline yellow dyeinduced fixed food-and-drug eruption. Contact Dermatitis 68:181-92.

Lemus-Mondaca R, Vega-Gálvez A, Zura-Bravo L, Ah-Hen K. 2012. Stevia rebaudiana Bertoni, source of a high-potency natural sweetener: A comprehensive review on the biochemical, nutritional and functional aspects. Food Chem 132:1121-32.

Lerner BW, Lerner KL. 2011. Food: In context. Cengage Learning, Farmington Hills, Michigan.

Leroux J, Langendorff V, Schick G, Vaishnav V, Mazoyer J. 2003. Emulsion stabilizing properties of pectin. Food Hydrocolloids 17:455-462. 
Li X, Shi X, Wang M, Du Y. 2011. Xylan chitosan conjugate - A potential food preservative. Food Chem 126:520-5.

Lin D, Zhao Y. 2007. Innovations in the development and application of edible coatings for fresh and minimally processed fruits and vegetables. Comp Rev Food Sci Food 6:60-75.

Lino CM, Pena A. 2010. Occurrence of caffeine, saccharin, benzoic acid and sorbic acid in soft drinks and nectars in Portugal and subsequent exposure assessment. Food Chem 121:503-8.

Liolios CC, Gortzi O, Lalas S, Tsaknis J, Chinou I. 2009. Liposomal incorporation of carvacrol and thymol isolated from the essential oil of Origanum dictamnus L. and in vitro antimicrobial activity. Food Chem 112:77-83.

Lodi F, Gartlon J, Kenigswald GK. 2011. The European Food Safety Authority (EFSA) re-evaluation of EU approved food additives. Toxicol Lett 205:S242-3.

Lofstedt R. 2013. Communicating food risks in an era of growing public distrust: Three case studies. Risk Anal 33:192-202.

Lu FC. 1988. Acceptable daily intake: Inception, evolution, and application. Regul Toxicol Parmacol 8:45-60.

Lucová M, Hojerová J, Pažoureková S, Klimová Z. 2013. Absorption of triphenylmethane dyes Brilliant Blue and Patent Blue through intact skin, shaven skin and lingual mucosa from daily life products. Food Chem Toxicol 52:19-27.

Lule SU, Xia W. 2005. Food phenolics, pros and cons: A review. Food Rev Int 21:36788.

Lv F, Liang H, Yuan Q, Li C. 2011. In vitro antimicrobial effects and mechanism of action of selected plant essential oil combinations against four food-related microorganisms. Food Res Int 44:3057-64. 
Macioszek VK, Kononowicz AK. 2004. The evaluation of the genotoxicity of two commonly used food colors: Quinoline yellow (E104) and brilliant black BN (E151). Cell Mol Biol Lett 9:107-22.

Maier E, Kurz K, Jenny M, Schennach H, Ueberall F, Fuchs D. 2010. Food preservatives sodium benzoate and propionic acid and colorant curcumin suppress Th1-type immune response in vitro. Food Chem Toxicol 48:1950-6.

Malheiros PS, Sant'Anna V, Barbosa MS, Brandelli A, Franco BDGM. 2012. Effect of liposome-encapsulated nisin and bateriosin-like substance P34 on Listeria monocytogenes growth in Minas frescal cheese. Int J Food Microbiol 156:272-7.

Mamur S, Yüzbaşioğlu D, Ünal F, Yilmaz S. 2010. Does potassium sorbate induce genotoxic or mutagenic effects in lymphocytes? Toxicol In Vitro 24:790-4.

Mamur S, Yüzbaşioğlu D, Ünal F, Aksoy H. 2012. Genotoxicity of food preservative sodium sorbate in lymphocytes in vitro. Cytotechnology 64:553-62.

Mangge H, Summers K, Almer G, Prassl R, Weghuber D, Schnedl W, Fuchs D. 2013. Antioxidant food supplements and obesity-related inflammation. Curr Med Chem 20:2330-7.

Maqsood S, Benjakul S, Shahidi F. 2013. Emerging role of phenolic compounds as natural additives in fish and fish products. Crit Rev Food Sci Nutr 53:162-79.

Martins AT, Santos FS, Scannavino FLF, Pires JR, Zuza EP, Junior JAP, Azoubel R, Mateo, MAS, Lopes RA. 2010. Effect of sodium cyclamate on the rat fetal exocrine pancreas: A karyometric and stereological study. Int J Morphol 28:899904.

Martyn DM, McNulty BA, Nugent AP, Gibney MJ. 2013. Food additives and preschool children. Proc Nutr Soc 72:109-16. 
May LT, Briddon SJ, Hill SJ. 2010. Antagonist selective modulation of adenosine $A_{1}$ and $\mathrm{A}_{3}$ receptor pharmacology by the food dye brilliant black $\mathrm{BN}$ : Evidence for allosteric interactions. Mol Pharmacol 77:678-86.

McCann D, Barrett A, Cooper A, Crumpler D, Dalen L, Grimshaw K, Kitchin E, Lok K, Porteous L, Prince E, Sonuga-Barke E, Stevenson J. 2007. Food additives and hyperactive behaviour in 3-yar-old and 8/9-year-old children in the community: A randomised, double-blind, placebo-controlled trial. Lancet 370:1560-7.

McFarlane M, Price SC, Cottrell S, Grasso P, Bremmer JN, Bomhard EM, Hinton RH 1997. Hepatic and associated response of rats to pregnancy, lactation and simultaneous treatment with butylated hydroxytoluene. Food Chem Toxicol $35: 753-61$.

Meeker JD, Yang T, Ye X, Calafat AM, Hauser R. 2011. Urinary concentrations of parabens and serum hormone levels, semen quality parameters and sperm DNA damage. Environ Health Persp 119:252-7.

Mepham B. 2011. Food additives: an ethical evaluation. Brit Med Bull 99:7-23.

Merusi C, Corradini C, Cavazza A, Borromei C, Salvadeo P. 2010. Determination of nitrates, nitrites and oxalates in food products by capillary electrophoresis with pH-dependent electro-osmotic flow reversal. Food Chem 120:615-20.

Mister S, Hathcock J. 2012. Under the law, FDA must grant different standards for new dietary ingredients and food additives. Regul Toxicol Pharm 62:456-8.

Moutinho ILD, Bertges LC, Assis RVC. 2007. Prolonged use of the food dye tartrazine (FD\&C yellow $\mathrm{n}^{0} 5$ ) and its effects on the gastric mucosa of Wistar rats. Braz $\mathrm{J}$ Biol 47:141-5. 
Mpountoukas P, Vantarakis A, Sivridis E, Lialiaris T. 2008. Cytogenetic study in cultured human lymphocytes treated with three commonly used preservatives. Food Chem Toxicol 46:2390-3.

Mpountoukas P, Pantazaki A, Kostareli E, Christodoulou P, Kareli D, Poliliou S, Mourelatos C, Lambropoulou V, Lialiaris T. 2010. Cytogenetic evaluation and DNA interaction studies of the food colorants amaranth, erythrosine and tartrazine. Food Chem Toxicol 48:2934-44.

Msagati TAM. 2013. The chemistry of food additives and preservatives. John Wiley \& Sons, West Sussex, UK.

Mukherjee A, Chakrabarti J. 1997. In vivo cytogenetic studies in mice exposed to acesulfame-K - a non-nutritive sweetener. Food Chem Toxicol 35:1177-9.

Nair B. 2001. Final report on the safety assessment of benzyl alcohol, benzoic acid and sodium benzoate. Int J Toxicol 20:23-50.

Nanditha B, Prabhasankar P. 2009. Antioxidants in bakery products: A review. Crit Rev Food Sci Nutr 49:1-27.

Nelis HJ, Leenheer AP. 2008. Microbial sources of carotenoid pigments used in foods and feeds. J Appl Bacteriol 70:181-91.

Nguefack J, Dongmo JBL, Dakole, CD, Leth V, Vismer HF, Torp J, Guemdjom EFN, Mbeffo M, Tamgue O, Fotio D, Zollo PHA, Nkengfack AE. 2009. Food preservative potential of essential oils and fractions from Cymbopogon citratus, Ocimum gratissimim and Thymus vulgaris against mycotoxigenic fungi. Int $\mathrm{J}$ Food Microbiol 131:151-6.

Nguyen ML, Schwartz SJ. 1998. Lycopene stability during food processing. Exp Biol Med 218:101-5. 
Nostro A, Blanco AR, Cannatelli MA, Enea V, Flamini G, Morelli I, Roccaro AS, Alonzo V. 2006. Susceptibility of methicillin-resistant staphylococci to oregano essential oil, carvacrol and thymol. Microbiol Lett 230:191-5.

Ohtsuki T, Sato K, Sugimoto N, Akiyama H, Kawamura Y. 2012. Absolute quantitative analysis for sorbic acid in processed foods using proton nuclear magnetic resonance spectroscopy. Anal Chim Acta 734: 54-61.

Oishi S. 2002. Effects of propyl paraben on the male reproductive system. Food Chem Toxicol 40:1807-13.

Olney JW. 1990. Excitotoxin-mediated neuron death in youth and old age. Prog Brain Res 86:37-51.

Olney JW. 1994. Excitotoxins in foods. Neurotoxicol 15:535-44.

Oms-Oliu G, Rojas-Graü MA, González LA, Varela P, Soliva-Fortuny R, Hernando MIH, Munuera IP, Fiszman S, Martín-Belloso O. 2010. Recent approaches using chemical treatments to preserve quality of fresh-cut fruit: A review. Postharvest Biol Tec 57:139-48.

Østerlie M, Lerfall J. 2005. Lycopene from tomato products added to minced meat: Effect on storage quality and colour. Food Res Int 38:925-9.

Park M, Park HR, Kim SJ, Kim M, Kong KH, Kim HS, Gong EJ, Kim ME, Kim HS, Lee BM, Lee J. 2009. Risk assessment for the combinatorial effects of food color additives: Neural progenitor cells and hippocampal neurogenesis. J Toxicol Environ Health A 72:21-2.

Patel AK, Michaud P, Singhania RR, Soccol CR, Pandey A. 2010. Polysacharides from probiotics: New developments as food additives. Food Technol Biotechnol 48:451-63. 
Peretto G, Du W, Avena-Bustillos RJ, Sarreal SBL, Hua SST, Sambo P, McHugh TH. 2014. Increasing strawberry shelf-life with carvacrol and methyl cinnamate antimicrobial vapors released from edible films. Postharvest Biol Tec 89:11-8.

Periago PM, Moezelaar R. 2001. Combined effect of nisin and carvacrol at different pH and temperature levels on the viability of different strains of Bacillus cereus. Int $\mathrm{J}$ Food Microbiol 68:141-8.

Pillai P, Ramaswamy K. 2012. Effect of naturally occurring antimicrobials and chemical preservatives on the growth of Aspergillus parasiticus. J Food Sci Technol 49:228-33.

Ponce AG, Roura SI, Valle CE, Moreira MR. 2008. Antimicrobial and antioxidant activities of edible coatings enriched with natural plant extracts: In vitro and in vivo studies. Postharvest Biol Tec 49:294-300.

Poul M, Jarry G, Elhkim MO, Poul J. 2009. Lack of genotoxicity effect of food dyes amaranth, sunset yellow and tartrazine and their metabolites in the gut micronucleus assay in mice. Food Chem Toxicol 47:443-8.

Pundir CS, Rawal R. 2013. Determination of sulfite with emphasis on biosensing methods: a review. Anal Bioanal Chem 405:3049-62.

Rannug U, Bramstedt H, Nilsson U. 1992. The presence of genotoxic and bioactive components in indigo dyed fabrics - a possible health risk? Mutat Res Lett 282:219-25.

Rasooli I. 2007. Food preservation - A biopreservative approach. Food 1:111-36.

Rencüzoğullari E, Íla HB, Kayraldiz A, Topaktaş M. 2001. Chromosome aberrations and sister chromatid exchanges in cultured human lymphocytes treated with sodium metabisulfite, a food preservative. Mutat Res 490:107-12. 
Renwick AG, Nordmann H. 2007. First European conference on aspartame: Putting safety and benefits into perspective. Synopsis of presentations and conclusions. Food Chem Toxicol 45:1308-13.

Renwick AG, Thompson JP. O'Shaughnessy M, Walter EJ. 2004. The metabolism of cyclamate to cyclohexylamine in humans during long-term administration. Toxicol Appl Pharmacol 196:367-80.

Reyes FGR, Valim MFCFA, Vercesi AE. 1993. Effect of organic synthetic food colours on mitochondrial respiration. Food Addit Contam 13:5-11.

Rezaei R, Knabe DA, Tekwe CD, Dahanayaka S, Ficken MD, Fielder SE, Eide SJ, Lovering SL, Wu G. 2013. Dietary supplementation with monosodium glutamate is a safe and improves growth performance in postweaning pigs. Amino Acids 44:911-23.

Roberts A, Renwick AG, Sims J, Snodin DJ. 2000. Sucralose metabolism and pharmacokinetics in man. Food Chem Toxicol 38:31-41.

Rodríguez-Trabado A, Miró J, Balagué I, Guspi R. 2007. Hypersensitivity to the antioxidant ethoxyquin. Actas Dermosifiliogr 98:580.

Rohman A, Man YC, Noviana E. 2013. Analysis of emulsifier in food using chromatographic techniques. J Food Pharm Technol 1:54-9.

Rycerz K, Jaworska-Adamu JE. 2013. Effects of aspartame metabolites on astrocytes and neurons. Folia Neuropathol 51:10-7.

Saad B, Bari MF, Saleh MI, Ahmad K, Talib MKM. 2005. Simultaneous determination of preservatives (benzoic acid, sorbic acid, methylparaben and propylparaben) in foodstuffs using high-performance liquid chromatography. J Chromatogr A 1073:393-7. 
Sacchetti G, Maietti S, Muzzoli M, Seaglianti M, Manfredini S, Radice M, Bruni R. 2005. Comprative evaluation of 11 essential oils of diferente origin as functional antioxidants, antiradicals and antimicrobials in foods. Food Chem 91:621-32.

Sanabria ERG, Pereira MFS, Dolnikoff MS, Andrade IS, Ferreira AT, Cavalheiro EA, Fernandes MJS. 2002. Deficit in hippocampal long-term potentiation in monosodium glutamate-treated rats. Brain Res Bull 59:47-51.

Sarikaya R, Selvi M, Erkoç F. 2012. Evaluation of portential geotoxicity of five food dyes using the somatic mutation and recombination test. Chemosphere 88:974-9.

Sasaki YF, Kawaguchi S, Kamaya A, Ohshita M, Kabasawa K, Iwama K, Taniguchi K, Tsuda S. 2002. The comet assay with 8 mouse: organs: results with 39 currently used food additives. Mutat Res 519:103-19.

Sayed HM, Fouad D, Ataya FS, Hassan NHA, Fahmy MA. 2012. The modifying effect of selenium and vitamins $\mathrm{A}, \mathrm{C}$ and $\mathrm{E}$ on the genotoxicity induced by sunset yellow in male mice. Mutat Res Genetic Toxicol Environ Muta 744:145-53.

Schnuch A, Lessmann H, Geier J, Uter W. 2011. Contact allergy to preservatives. Analysis of IVDK data 1996-2009. Brit J Dermatol 164:1316-25.

Scognamiglio J, Jones L, Vitale D, Letizia CS, Api AM. 2012. Fragrance material review on benzyl alcohol. Food Chem Toxicol 50:5140-60.

Scotter M. 2009. The chemistry and analysis of annatto food colouring: a review. Food Addit Contam A 26:1123-45.

Sebranek JG, Bacus JN. 2007. Meat products without direct addition of nitrate or nitrite: What are the issues? Meat Sci 77:136-47.

Serra AT, Matias AA, Nunes AVM, Leitão MC, Brito D, Bronze R, Silva S, Pires A, Crespo MT, Romão MVS, Duarte CM 2008. In vitro evaluation of olive- and 
grape-based natural extracts as potential preservatives for food. Innov Food Sci Emerg Technol 9:311-9.

Shahabadi N, Maghsudi M, Rouhani S. 2012. Study on the interaction of food colourant quinoline yellow with bovine serum albumin by spectroscopic techniques. Food Chem 135:1836-41.

Shahidi F, Zhong T. 2010. Novel antioxidants in food quality preservation and health promotion. Eur J Lipid Sci Technol 112:930-40.

Shankar P, Ahuja S, Sriram K. 2013. Non-nutritive sweeteners: Reviews and update. Nutrition 29:1293-9.

Shi Z, Luscombe-Marsh ND, Wittert GA, Tuan B, Dai Y, Pan X, Taylor AW. 2010. Monosodium glutamate is not associated with obesity or a greater prevalence of weight gain over 5 years: Findings from the Jiangsu Nutrition Study of Chinese adults. Brit J Nutr 104:457-63.

Shim S, Seo SH, Lee Y, Moon G, Kim M, Park J. 2011. Consumers' knowledge and safety perceptions of food additives: Evaluation on the effectiveness of transmitting information on preservatives. Food Control 22:1054-80.

Shimada C, Kano K, Sasaki YF, Sato I, Tsuda S. 2010. Differential colon DNA damage induced by azo food additives between rats and mice. J Toxicol Sci 35: 547-54.

Sims J, Roberts A, Daniel JW, Renwick AG. 2000. The metabolic fate of sucralose in rats. Food Chem Toxicol 38:115-21.

Sindelar JJ, Milkowski AL. 2012. Human safety controversies surrounding nitrate and nitrite in the diet. Nitric Oxide 26:259-66.

Singh K, Ahluwalia P. 2012. Effect of monosodium glutamate on lipid peroxidation and certain antioxidant enzymes in cardiac tissue of alcoholic adult male mice. J Cardiovasc Dis Res 3:12-8. 
Skurtys O, Acevedo C, Pedreschi F, Enrione J, Osorio F, Aguilera JM. Food hydrocolloid edible films and coatings. Nova Science Publishers, New York, USA.

Smith MR, Wilson R, Hepburn PA. 1998. Assessment of the carcinogenic potential of polyglycerol polyricinoleate (PGPR) in rats and mice. Food Chem Toxicol $36: 747-54$.

Smith-Palmer A, Stewart J, Fyfe L. 2001. The potential application of plant essential oils as natural food preservatives in soft cheese. Food Microbiol 18:463-70.

Soffritti M. 2006. Acesulfame potassium: Soffritti responds. Environ Health Persp 114:516-7.

Spencer PJ. 2005. New toxicity data for the propylene glycol ethers-a commitment to public health and safety. Toxicol Lett 156:181-8.

Stolz A. 2001. Basic and applied aspects in the microbial degradation of azo dyes. Appl Microbiol Biotechnol 56:69-80.

Suh H, Cho Y, Chung M, Kim B. 2007. Preliminary data on sulphite intake from the Korean diet. J Food Comp Anal 20:212-9.

Sung S, Sin LT, Tee T, Bee S, Rahmat AR, Rahman WAWA, Tan A, Vikhraman M. 2013. Antimicrobial agents for food packaging applications. Trends Food Sci Tec $33: 110-123$.

Swithers SE, Martin AA, Davidson TL. 2010. High-intensity sweeteners and energy balance. Physiol Behav 100:55-62.

Tajkarimi MM, Ibrahim SA, Cliver DO. 2010. Antimicrobial herb and spice compounds in food. Food Control 21:1199-218. 
Takayama S, Renwick AG, Johansson SL, Thorgeirsson UP, Tsutsumi M, Dalgard DW, Sieber SM. 2000. Long-term toxicity and carcinogenicity study of cyclamate in nonhuman primates. Toxicol Sci 53:33-9.

Tanaka T. 2001. Reproductive and neurobehavioral toxicity study of erythrosine administered to mice in the diet. Food Chem Toxicol 39:447-54.

Tanaka T. 2006. Reproductive and neurobehavioural toxicity study of tartrazine administered to mice in the diet. Food Chem Toxicol 44:179-87.

Tanaka T, Takahashi O, Inomata A, Ogata A, Nakae D. 2012. Reproductive and neurobehavioral effects of brilliant blue FCF in mice. Birth Defects Res Part B 95:395-409.

Tanaka T, Takahashi O, Oishi S, Ogata A. 2008. Effects of tartrazine on exploratory behaviour in a three-generation toxicity study in mice. Reprod Toxicol 26:156-63.

Tandel K.R. 2011. Sugar substitutes: Health controversy over perceived benefits. J Pharmacol Pharmacother 2:236-43.

Tatsuishi T, Oyama Y, Iwase K, Yamaguchi J, Kobayashi M, Nishimura Y, Hirama S. 2005. Polysorbate 80 increases the susceptibility to oxidative stress in rat thymoytes. Toxicol 207:7-14.

Tavares RS, Martins FC, Oliveira PJ, Ramalho-Santos J, Peixoto FP. 2009. Parabens in male infertility-Is there a mitochondrial connection? Reprod Toxicol 27:1-7.

Tayama S, Nakagawa Y. 2001. Cytogenetic effects of propyl gallate in CHO-K1 cells. Mutat Res 498:117-27.

Thomas JA, DeSesso JM, Fowler BA, Ginsberg GL, Hansen D, Hines CJ, Hines R, Portier K, Rozman K. 2004. NTP-CERHR Expert Panel report on the reproductive and developmental toxicity of propylene glycol. Reprod Toxicol 18:533-79. 
Tian S, Tang J, Liu H, Wang L, Shen J, Li J, Gan Y. 2012. Propyl gallate plays a nephroprotective role in early stage of diabetic nephropathy associated with suppression of glomerular endothelial cell proliferation and angiogenesis. J Diabetes Res 2012:1-8.

Tiwari BK, Valdramidis VP, O’Donnell CP, Muthukumarappan K, Bourke P, Cullen, PJ. 2009. Application of natural antimicrobials to food preservation. J Agric Food Chem 57:5987-6000.

Tobacman JK. 2001. Review of harmful gastrointestinal effects of carrageenan in animal experiments. Environ Health Persp 109:983-94.

Tsay H, Wang Y, Chen W, Huang M, Chen Y. 2007. Treatment with sodium benzoate leads to malformation of zebrafish larvae. Neurotoxicol Teratol 29:562-9.

Tsuda S, Murakami M, Matsusaka N, Kano K, Taniguchi K, Sasaki YF. 2001. DNA damage induced by red food dyes orally administered to pregnant male mice. Toxicol Sci 61:92-9.

Turgis M, Vu KD, Dupont C, Lacroix M. 2012. Combined antimicrobial effect of essential oils and bacteriocins against foodborne pathogens and food spoilage bacteria. Food Res Int 48:696-702.

Türkoğlu S. 2008. Evaluation of genotoxic effects of sodium propionate and potassium propionate on the root meristem cells of Allium cepa. Food Chem Toxicol 46:2035-41.

Tyagi AK, Malik A. 2011. Antimicrobial potential and chemical composition of Mentha piperita oil in liquid and vapour phase against food spoiling microorganisms. Food Control 22:1707-17. 
Udompijitkul P, Paredes-Sabja D, Sarker MR. 2012. Inhibitory effects of nisin against Clostridium perfringens food poisoning and nonfood-borne isolates. J Food Sci $71: 51-6$

Ulca P, Atamer B, Keskin M, Senyuva HZ. 2013. Sorbate and benzoate in Turkish retail foodstuffs. Food Addit Contam B 6:209-13.

Ulca P, Öztürk Y, Senyuva HZ. 2011. Survey of sulphites in wine and various Turkish food and food products intended for export, 2007-2010. Food Addit Contam B 4:226-30.

Ultee A, Smid EJ. 2001. Influence of carvacrol on growth and toxin production by Bacillus cereus. Int J Food Microbiol 64:373-8.

Ultee A, Bennik MHJ, Moezelaar R. 2002. The phenolic hydroxyl group of carvacrol is essential for action against the food-borne pathogen Bacillus cereus. Appl Environ Microbiol 68:1561-8.

Valencia-Chamorro SA, Palou L, Río MA, Pérez-Gago MB. 2011. Antimicrobial edible films and coatings for fresh and minimally processed fruits and vegetables: A review. Crit Rev Food Sci Nutr 51:872-900.

Vally H, Misso NLA, Madan V. 2009. Clinical effects of sulphite additives. Clin Exp Allergy 39:1643-51.

Vandevijvere S, Temme E, Andjelkovic M, Will MD, Goeyens L, Loco JV. 2010. Estimate of intake of sulphites in the Belgian adult population. Food Addit Contam A 27:1072-83.

Vandghanooni S, Forouharmehr A, Eskandani M, Barzegari A, Kashanian S, Nazhad E, Dolatabadi J. 2013. Cytotoxicity and DNA fragmentation properties of butylated hydroxyanisole. DNA Cell Biol 32:98-103. 
Varela P, Fiszman SM. 2013. Exploring consumers' knowledge and perceptions of hydrocolloids used as food additives and ingredients. Food Hydrocolloids 30:47784.

Viberg H, Fredriksson A. 2011. Neonatal exposure to sucralose does not alter biochemical markers of neuronal development or adult behaviour. Nutrition $27: 81-5$

Walker R, Lupien JR. 2000. The safety evaluation of monosodium glutamate. J Nutr 130:1049-52.

Wang L, Zhang X, Wang Y, Wang W. 2006. Simultaneous determination of preservatives in soft drinks, yogurts and sauces by a novel solid-phase extraction element and thermal desorption-gas chromatography. Anal Chim Acta 577:62-7.

Watson DH. 2002. Food chemical safety. Volume 2: Additives. Woodhead Publishing Limited, Cambridge, UK.

Weihrauch MR, Diehl V. 2004. Artificial sweeteners - do they bear a carcinogenic risk? Ann Oncol 15:1460-65.

Weiner ML, Nuber D, Blakemore WR, Hariman JF, Cohen SM. 2007. A 90-day dietary study on kappa-carrageenan with emphasis on the gastrointestinal tract. Food Chem Toxicol 45:98-106.

Werley MS, McDonald P, Lilly P, Kirkpatrick D, Wallery J, Byron P, Venitz J. 2011. Non-clinical safety and pharmacokinetic evaluations of propylene glycol aerosol in Sprague-Dawley rats and Beagle dogs. Toxicol 287:76-90.

Williams GM, Iatropoulus MJ, Whysner J. 1999. Safety assessment of butylated hydroxyanisole and butylated hydroxytoluene as antioxidant food additives. Food Chem Toxicol 37:1027-38. 
Wilson R, Smith M. 1998. Human studies on polyglycerol polyricinoleate (PGPR). Food Chem Toxicol 36:743-5.

Wilson TA, Meservey CM, Nicolosi RJ. 1998. Soy lecithin reduced plasma lipoprotein cholesterol and early atherogenesis in hypercholesterolemic monkeys and hamsters: Beyond linoleate. Atherosclerosis 140:147-53.

Whysner J, Williams GM. 1996a. Butylated hydroxyanisole mechanistic data and risk assessment: Conditional species-species cytotoxicity, enhanced cell proliferation, and tumour promotion. Pharmacol Therapeut 71:137-51.

Whysner J, Williams GM. 1996b. Saccharin mechanism data and risk assessment: Urine composition, enhanced cell proliferation, and tumor promotion. Pharmacol Therapeut 71:225-52.

WHO, World Health Organization. 2000. Concise International Chemical Assessment Document. Benzoic acid and sodium benzoate. Accessed July 2013. Available from: http://www.who.int/ipcs/publications/cicad/cicad26_rev_1.pdf

Xia W, Liu P, Zhang J, Chen J. 2011. Biological activities of chitosan and chitooligosaccharides. Food Hydrocolloids 25:170-9.

Xiu-Qin L, Chao J, Yan-Yan S, Min-Li Y, Xiao-Gang C. 2009. Analysis of synthetic antioxidants and preservatives in edible vegetable oil by HPLC/TOF-MS. Food Chem 113:692-700.

Xu J, Zhou F, Ji BP, Pei RS, Xu N. 2008. The antibacterial mechanism of carvacrol and thymol against Escherichia coli. Lett Appl Microbiol 47:174-9.

Yadav A, Kumar A, Tripathi A, Das M. 2013. Sunset yellow FCF, a permitted food dye, alters functional responses of splenocytes at a non-cytotoxic dose. Toxicol Lett 217:197-204. 
Yang B, Bhattacharyya S, Linhardt R, Tobacman J. 2012. Exposure to common food additive carrageenan leads to reduced sulfatase activity and increase in sulphated glycosaminoglycans in human epithelial cells. Biochimie 94:1309-16.

Yao LH, Jiang YM, Shi J, Tomás-Barberán FA, Datta N, Singanusong R, Chen SS. 2004. Flavonoids in food and their health benefits. Plant Food Hum Nutr 59:11322.

Ye H, Shen S, Xu J, Lin S, Yuan Y, Jones GS. 2013. Synergistic interaction of cinnamaldehyde in combination with carvacrol against food-borne bacteria. Food Control 34:619-23.

Yilmaz S, Ünal F, Yüzbaşioğlu D. 2009. The in vitro genotoxicity of benzoic acid in human peripheral blood lymphocytes. Cytotechnology 60:55-61.

Yilmaz S, Ünal F, Yüzbaşioğlu D, Çelik M. 2008. Cytogenetic effects of citric acid and benzoic acid on Allium chromosomes. Fresen Environ Bull 17:1029-37.

Yoshikawa K, Saito S, Sakuragawa A. 2011. Simultaneous analysis of acidulants and preservatives in food samples by using capillary zone electrophoresis with indirect UV detection. Food Chem 127:1385-90.

Yoshioka N, Ichihashi K. 2008. Determination of 40 synthetic food colors in drinks and candies by high-performance liquid chromatography using a short column with photodiode array detection. Talanta 74:1408-13.

Zengin N, Yüzbaşioğlu D, Ünal F, Aksoy H. 2011. The evaluation of the genotoxicity of two food preservatives: Sodium benzoate and potassium benzoate. Food Chem Toxicol 49:763-9.

Zhang G, Ma Y. 2013a. Spectroscopic studies on the interaction of sodium benzoate, a food preservative, with calf thymus DNA. Food Chem 141:41-7. 
Zhang G, Ma, Y. 2013b. Mechanistic and conformational studies on the interaction of food dye amaranth with human serum albumin by multispectroscopic methods. Food Chem 136:442-9.

Zurita JL, Jos Á, Peso A, Salguero M, López-Artíguez M, Repetto G. 2007. Ecotoxicological effects of the antioxidant additive propyl gallate in five aquatic systems. Water Res 41 2599-611. 
Table 1-Antimicrobial food additives with use restrictions and their respective ADI quantities (mg/kg bw)

\begin{tabular}{|c|c|c|c|c|}
\hline E number & Name & Legislation & ADI & References \\
\hline E210 & Benzoic acid & $\begin{array}{c}\text { Code of Federal } \\
\text { Regulations } 21 \\
\text { Sec.184.1021 } \\
- \\
\text { EU Regulation No. } \\
1129 / 2011\end{array}$ & $\begin{array}{c}5 \mathrm{mg} / \mathrm{kg} \\
\mathrm{bw}\end{array}$ & $\begin{array}{c}\text { WHO 2000 } \\
\text { Nair 2001 } \\
\text { Yilmaz and others } 2008 \\
\text { Yilmaz and others } 2009 \\
\text { Zengin and others 2011 } \\
\text { Cakir and Cagri-Mehmetoglu } \\
2013\end{array}$ \\
\hline E211 & Sodium benzoate & $\begin{array}{c}\text { Code of Federal } \\
\text { Regulations } 21 \\
\text { Sec.184.1733 } \\
- \\
\text { EU Regulation No. } \\
1129 / 2011\end{array}$ & $\begin{array}{c}5 \mathrm{mg} / \mathrm{kg} \\
\mathrm{bw}\end{array}$ & $\begin{array}{c}\text { Nair } 2001 \\
\text { McCann and others } 2007 \\
\text { Tsay and others } 2007 \\
\text { Beezhold and others } 2012 \\
\text { Ciardi and others } 2012 \\
\text { Mangge and others 2013 } \\
\text { Zhang and Ma 2013a }\end{array}$ \\
\hline E214 & $\begin{array}{c}\text { Ethyl-p- } \\
\text { hydroxybenzoate } \\
\text { (paraben) }\end{array}$ & $\begin{array}{c}\text { Code of Federal } \\
\text { Regulations } 21 \\
\text { Sec.175.105 } \\
- \\
\text { EU Regulation No. } \\
1129 / 2011\end{array}$ & $\begin{array}{c}10 \mathrm{mg} / \mathrm{kg} \\
\mathrm{bw}\end{array}$ & \multirow{4}{*}{$\begin{array}{c}\text { Oishi } 2002 \\
\text { Darbre and others } 2004 \\
\text { Harvey and Everett } 2004 \\
\text { Tavares and others } 2009 \\
\text { Meeker and others } 2011 \\
\text { Aubert and others } 2012 \\
\text { Castelain and Castelain 2012 }\end{array}$} \\
\hline E215 & $\begin{array}{l}\text { Sodium ethyl p- } \\
\text { hydroxybenzoate } \\
\text { (parabens) }\end{array}$ & $\begin{array}{c}\text { Code of Federal } \\
\text { Regulations } 21 \\
\text { Sec.175.105 } \\
\quad- \\
\text { EU Regulation No. } \\
1129 / 2011\end{array}$ & $\begin{array}{c}10 \mathrm{mg} / \mathrm{kg} \\
\mathrm{bw}\end{array}$ & \\
\hline E218 & $\begin{array}{l}\text { Methyl p- } \\
\text { hydroxybenzoate } \\
\text { (parabens) }\end{array}$ & $\begin{array}{c}\text { Code of Federal } \\
\text { Regulations } 21 \\
\text { Sec.150.141 } \\
- \\
\text { EU Regulation No. } \\
\text { 1129/2011 }\end{array}$ & $\begin{array}{c}10 \mathrm{mg} / \mathrm{kg} \\
\mathrm{bw}\end{array}$ & \\
\hline E219 & $\begin{array}{l}\text { Sodium methyl p- } \\
\text { hydroxybenzoate } \\
\text { (paraben) }\end{array}$ & $\begin{array}{c}\text { Banned in the USA } \\
- \\
\text { EU Regulation No. } \\
1129 / 2011\end{array}$ & $10 \mathrm{mg} / \mathrm{kg}$ & \\
\hline E200 & Sorbic acid & $\begin{array}{l}\text { Code of Federal } \\
\text { Regulations } 21\end{array}$ & $\begin{array}{c}25 \mathrm{mg} / \mathrm{kg} \\
\mathrm{bw}\end{array}$ & $\begin{array}{l}\text { Binstok and others } 1998 \\
\text { Ferrand and others } 2000\end{array}$ \\
\hline
\end{tabular}


Sec.182.3089

EU Regulation No.

1129/2011

Code of Federal

Regulations 21

E201 Sodium sorbate

Sec.182.3089

$25 \mathrm{mg} / \mathrm{kg}$

Jung and others 1992

bw

Mamur and others 2012

Not approved in the EU

Code of Federal

Regulations 21

E202 Potassium sorbate $\begin{array}{cc}25 \mathrm{mg} / \mathrm{kg} & \text { Mpountoukas and others } 2008 \\ \mathrm{bw} & \text { Mamur and others } 2010\end{array}$

EU Regulation No. 1129/2011

Code of Federal

Regulations 21

Sec.182.3616, 3637,

E220 -

E228

Sulfites

3739, 3766, 3798

EU Regulation No. 1129/2011

Code of Federal

Regulations 21

E249 Potassium nitrite

E250

Sodium nitrite

Sec. 172.160

EU Regulation No. 1129/2011

Code of Federal

Regulations 21

Sec. 172.175

EU Regulation No. 1129/2011

Code of Federal

Regulations 21

E281

Sodium

propionate
Sec.184.1784

EU Regulation No.
Rencüzoğullari and others 2001

Suh and others 2007

Cressey and Jones 2009

Vally and others 2009

Vandevijvere and others 2010

Ulca and others 2011

García-Gavín and others 2012

Cammack and others 1999

Sebranek and Bacus 2007

Hord and others 2009 $\mathrm{mg} / \mathrm{kg}$ bw

Cammack and others 1999

Chow and Hong 2002

Sebranek and Bacus 2007

Hord and others 2009

Chan 2011

Hord 2011

bw $\quad$ Hord and others 2009

$1129 / 2011$ 
Table 2-Antioxidant food additives with use restrictions and their respective ADI quantities ( $\mathrm{mg} / \mathrm{kg}$ bw)

\begin{tabular}{|c|c|c|c|c|}
\hline E number & Name & Legislation & ADI & References \\
\hline E310 & $\begin{array}{l}\text { Propyl galate } \\
\text { (PG) }\end{array}$ & $\begin{array}{c}\text { Code of Federal } \\
\text { Regulations } 21 \\
\text { Sec.184.1660 } \\
- \\
\text { EU Regulation No. } \\
\text { 1129/2011 }\end{array}$ & $\begin{array}{c}1.4 \mathrm{mg} / \mathrm{kg} \\
\mathrm{bw}\end{array}$ & $\begin{array}{c}\text { Jacobi and others } 1998 \\
\text { Branen and others } 2001 \\
\text { Tayama and Nakagawa } 2001 \\
\text { Chen and others } 2011 \\
\text { Zurita and others } 2007 \\
\text { Amadasi and others., } 2009 \\
\text { Han and Park 2009 } \\
\text { Tian and others } 2012\end{array}$ \\
\hline E319 & $\begin{array}{l}\text { tert- } \\
\text { butylhydroquino } \\
\text { ne (TBHQ) }\end{array}$ & $\begin{array}{c}\text { Code of Federal } \\
\text { Regulations } 21 \\
\text { Sec. } 172185 \\
- \\
\text { EU Regulation No. } \\
\text { 1129/2011 } \\
\end{array}$ & $\begin{array}{c}0.7 \mathrm{mg} / \mathrm{kg} \\
\mathrm{bw}\end{array}$ & $\begin{array}{c}\text { Whysner and Williams 1996a } \\
\text { EFSA } 2004\end{array}$ \\
\hline E320 & $\begin{array}{l}\text { Butylated } \\
\text { hydroxyanisole } \\
\text { (BHA) }\end{array}$ & $\begin{array}{c}\text { Code of Federal } \\
\text { Regulations } 21 \\
\text { Sec. } 172.110 \\
- \\
\text { EU Regulation No. } \\
\text { 1129/2011 } \\
\end{array}$ & $\begin{array}{c}0.5 \mathrm{mg} / \mathrm{kg} \\
\mathrm{bw}\end{array}$ & $\begin{array}{c}\text { Whysner and Williams 1996a } \\
\text { Jeong and others } 2005 \\
\text { EFSA 2011 } \\
\text { Ali and Suziki } 2012 \\
\text { Carocho and Ferreira 2013a } \\
\text { Vandghanooni and others } 2013\end{array}$ \\
\hline E321 & $\begin{array}{l}\text { Butylated } \\
\text { hydroxytoluene } \\
(\mathrm{BHT})\end{array}$ & $\begin{array}{c}\text { Code of Federal } \\
\text { Regulations } 21 \\
\text { Sec. } 172.115 \\
- \\
\text { EU Regulation No. } \\
1129 / 2011 \\
\end{array}$ & $\begin{array}{l}0.05 \mathrm{mg} / \mathrm{kg} \\
\text { bw }\end{array}$ & $\begin{array}{c}\text { McFarlane and others } 1997 \\
\text { Williams and others } 1999 \\
\text { Botterweck and others } 2000 \\
\text { Engin and others } 2011 \\
\text { EFSA 2012a } \\
\text { Carocho and Ferreira 2013a }\end{array}$ \\
\hline E324 & $\begin{array}{l}\text { Ethoxyquin } \\
\text { (EQ) }\end{array}$ & $\begin{array}{c}\text { Code of Federal } \\
\text { Regulations } 21 \\
\text { Sec. } 172.140 \\
- \\
\text { EU Regulation No. } \\
1129 / 2011 \\
\end{array}$ & $\begin{array}{c}0.005 \\
\mathrm{mg} / \mathrm{kg} \mathrm{bw}\end{array}$ & $\begin{array}{c}\text { Błaszczyk and others } 2003 \\
\text { Rodríguez-Trabado and others } \\
2007 \\
\text { Błaszczyk and others } 2013\end{array}$ \\
\hline
\end{tabular}


Table 3-Azo compounds of dyes with use restrictions and their respective ADI quantities ( $\mathrm{mg} / \mathrm{kg} \mathrm{bw}$ )

\begin{tabular}{|c|c|c|c|c|}
\hline E number & Name & Legislation & ADI & References \\
\hline E102 & $\begin{array}{c}\text { Tartrazine } \\
- \\
\text { FD\&C Yellow } \\
\text { No. } 5\end{array}$ & $\begin{array}{c}\text { Code of Federal } \\
\text { Regulations } 21 \\
\text { Sec.74.1705 } \\
- \\
\text { EU Regulation No. } \\
\quad 1129 / 2011\end{array}$ & $\begin{array}{c}7.5 \mathrm{mg} / \mathrm{kg} \\
\mathrm{bw}\end{array}$ & $\begin{array}{c}\text { Tanaka } 2006 \\
\text { Moutinho and others } 2007 \\
\text { Tanaka and others } 2008 \\
\text { Poul and others } 2009 \\
\text { Amin and others } 2010 \\
\text { Mpountoukas and others } 2010 \\
\text { Gao and others } 2011 \\
\text { Axon and others } 2012\end{array}$ \\
\hline E110 & $\begin{array}{l}\text { Sunset yellow } \\
- \\
\text { FD\&C Yellow } \\
\text { No. } 6\end{array}$ & $\begin{array}{c}\text { Code of Federal } \\
\text { Regulations } 21 \\
\text { Sec.74.1706 } \\
- \\
\text { EU Regulation No. } \\
\text { 1129/2011 } \\
\end{array}$ & $\begin{array}{c}2.5 \mathrm{mg} / \mathrm{kg} \\
\mathrm{bw}\end{array}$ & $\begin{array}{l}\text { Axon and others } 2012 \\
\text { Sayed and others } 2012 \\
\text { Ceyhan and others } 2013 \\
\text { Yadav and others } 2013\end{array}$ \\
\hline E122 & Carmoisine & $\begin{array}{c}\text { No permission sought in } \\
\text { the USA } \\
- \\
\text { EU Regulation No. } \\
1129 / 2011 \\
\end{array}$ & $\underset{\mathrm{bw}}{4 \mathrm{mg} / \mathrm{kg}}$ & $\begin{array}{l}\text { Amin and others } 2010 \\
\text { Arvin and others } 2013 \\
\text { Datta and others } 2013\end{array}$ \\
\hline E123 & Amaranth & $\begin{array}{c}\text { Banned in the USA } \\
- \\
\text { EU Regulation No. } \\
1129 / 2011\end{array}$ & $\begin{array}{c}0.8 \mathrm{mg} / \mathrm{kg} \\
\mathrm{bw}\end{array}$ & $\begin{array}{c}\text { Sasaki and others } 2002 \\
\text { Mpountoukas and others } 2010 \\
\text { Poul and others } 2012 \\
\text { Sarikaya and others } 2012\end{array}$ \\
\hline E129 & $\begin{array}{c}\text { Allura red } \\
- \\
\text { FD\&C Red No. } \\
40\end{array}$ & $\begin{array}{c}\text { Code of Federal } \\
\text { Regulations } 21 \\
\text { Sec. } 74.340 \\
- \\
\text { EU Regulation No. } \\
1129 / 2011\end{array}$ & $\underset{\mathrm{bw}}{7 \mathrm{mg} / \mathrm{kg}}$ & $\begin{array}{c}\text { Tsuda and others } 2001 \\
\text { Shimada and others } 2010 \\
\text { Ceyhan and others } 2013 \\
\text { Abramsson-Zetterberg and } \\
\text { Ilbäck } 2013\end{array}$ \\
\hline
\end{tabular}


Table 4-Triarylmethane compounds of dyes with use restrictions and their respective ADI quantities $(\mathrm{mg} / \mathrm{kg}$ bw)

\begin{tabular}{|c|c|c|c|c|}
\hline E number & Name & Legislation & ADI & References \\
\hline E131 & Patent blue & $\begin{array}{c}\text { Banned in the USA } \\
\text { - } \\
\text { EU Regulation No. } \\
1129 / 2011\end{array}$ & $\begin{array}{l}15 \mathrm{mg} / \mathrm{kg} \\
\mathrm{bw}\end{array}$ & $\begin{array}{l}\text { Sarikaya and others } 2012 \\
\text { Lucová and others } 2013\end{array}$ \\
\hline E133 & $\begin{array}{c}\text { Brilliant blue } \\
\text { FD\&C Blue No. } \\
1\end{array}$ & $\begin{array}{c}\text { Code of Federal } \\
\text { Regulations } 21 \\
\text { Sec. } 74.101 \\
- \\
\text { EU Regulation No. } \\
1129 / 2011\end{array}$ & $\begin{array}{c}10 \mathrm{mg} / \mathrm{kg} \\
\mathrm{bw}\end{array}$ & $\begin{array}{l}\text { Tanaka and others } 2012 \\
\text { Lucová and others } 2013\end{array}$ \\
\hline E142 & Brilliant green & $\begin{array}{c}\text { No permission sought in } \\
\text { the USA } \\
- \\
\text { EU Regulation No. } \\
1129 / 2011\end{array}$ & $\begin{array}{c}5 \mathrm{mg} / \mathrm{kg} \\
\mathrm{bw}\end{array}$ & EFSA $2010 b$ \\
\hline E143 & $\begin{array}{c}\text { Fast green } \\
- \\
\text { FD\&C Green } \\
\text { No. } 3\end{array}$ & $\begin{array}{c}\text { Code of Federal } \\
\text { Regulations } 21 \\
\text { Sec.74.203 } \\
- \\
\text { Banned in the EU }\end{array}$ & $\begin{array}{l}25 \mathrm{mg} / \mathrm{kg} \\
\mathrm{bw}\end{array}$ & Ha and others 2013 \\
\hline E151 & Brilliant black & $\begin{array}{c}\text { No permission sought in } \\
\text { the USA } \\
- \\
\text { EU Regulation No. } \\
1129 / 2011 \\
\end{array}$ & $\begin{array}{c}5 \mathrm{mg} / \mathrm{kg} \\
\mathrm{bw}\end{array}$ & $\begin{array}{l}\text { Macioszek and Kononowicz } \\
2004 \\
\text { May and others } 2010\end{array}$ \\
\hline
\end{tabular}


Table 5-Sweeteners with use restrictions and their respective ADI quantities ( $\mathrm{mg} / \mathrm{kg} \mathrm{bw}$ )

\begin{tabular}{|c|c|c|c|c|}
\hline E number & Name & Legislation & ADI & References \\
\hline E950 & Acesulfame K & $\begin{array}{c}\text { Code of Federal } \\
\text { Regulations } 21 \\
\text { Sec. } 172.800 \\
- \\
\text { EU Regulation No. } \\
\text { 1129/2011 } \\
\end{array}$ & $\begin{array}{c}15 \mathrm{mg} / \mathrm{kg} \\
\mathrm{bw}\end{array}$ & $\begin{array}{c}\text { Mukherjee and Chakrabart } 1997 \\
\text { EFSA } 2000 \\
\text { Karstadt } 2006 \\
\text { Soffritti } 2006\end{array}$ \\
\hline E952 & Cyclamates & $\begin{array}{c}\text { Banned in the USA } \\
- \\
\text { EU Regulation No. } \\
1129 / 2011\end{array}$ & $11 \underset{\mathrm{bw}}{\mathrm{mg} / \mathrm{kg}}$ & $\begin{array}{l}\text { Takayama and others } 2000 \\
\text { Martins and others } 2010 \\
\text { Renwick and others } 2004\end{array}$ \\
\hline E954 & Saccharin & $\begin{array}{l}\text { Code of Federal } \\
\text { Regulations } 21 \\
\quad \text { Sec. } 180.37 \\
- \\
\text { EU Regulation No. } \\
\quad 1129 / 2011 \\
\end{array}$ & $\begin{array}{c}5 \mathrm{mg} / \mathrm{kg} \\
\mathrm{bw}\end{array}$ & $\begin{array}{c}\text { Whysner and Williams } 1996 \mathrm{~b} \\
\text { Dybing } 2002 \\
\text { Bandyopadhyay and others } \\
2008 \\
\text { Swithers and others } 2010 \\
\text { Feijó and others } 2013\end{array}$ \\
\hline E955 & Sucralose & $\begin{array}{c}\text { Code of Federal } \\
\text { Regulations } 21 \\
\text { Sec. } 172.831 \\
- \\
\text { EU Regulation No. } \\
\quad 1129 / 2011 \\
\end{array}$ & $\begin{array}{c}5 \mathrm{mg} / \mathrm{kg} \\
\mathrm{bw}\end{array}$ & $\begin{array}{l}\text { Abou-Donia and others } 2000 \\
\text { Baird and others } 2000 \\
\text { Roberts and others } 2000 \\
\text { Sims and others } 2000 \\
\text { Brusick and others } 2009 \\
\text { Brusick and others } 2010 \\
\text { Viberg and Fredriksson } 2011 \\
\end{array}$ \\
\hline E962 & Aspartame & $\begin{array}{c}\text { Code of Federal } \\
\text { Regulations } 21 \\
\text { Sec. } 172.804 \\
- \\
\text { EU Regulation No. } \\
1129 / 2011\end{array}$ & $\begin{array}{c}40 \mathrm{mg} / \mathrm{kg} \\
\mathrm{bw}\end{array}$ & $\begin{array}{l}\text { Renwick and Nordmann } 2007 \\
\text { Abhilash and others } 2011 \\
\text { Ashok and others } 2013 \\
\text { Rycerz and Jaworsaka-Adamu } \\
2013\end{array}$ \\
\hline- & $\begin{array}{l}\text { Fructose (high- } \\
\text { fructose corn } \\
\text { syrup) }\end{array}$ & $\begin{array}{c}\text { Code of Federal } \\
\text { Regulations } 21 \\
\text { Sec.184.1866 } \\
- \\
\text { Not considered a food } \\
\text { additive in the EU }\end{array}$ & $\begin{array}{l}\text { No } \\
\text { limitation }\end{array}$ & $\begin{array}{c}\text { CFR } 2003 \\
\text { Bray } 2004 \\
\text { EFSA } 2008\end{array}$ \\
\hline- & Sucrose & $\begin{array}{c}\text { Code of Federal } \\
\text { Regulations } 21 \\
\text { Sec.184.1854 } \\
- \\
\text { Not considered a food } \\
\text { additive in the EU }\end{array}$ & $\begin{array}{c}\text { No } \\
\text { limitations }\end{array}$ & $\begin{array}{l}\text { CFR } 2003 \\
\text { EFSA } 2008 \\
\text { Anton } 2010\end{array}$ \\
\hline E957 & Thaumatin & $\begin{array}{c}\text { EAFUS Doc No. } 2849 \\
- \\
\text { EU Regulation No. } \\
\text { 1129/2011 }\end{array}$ & $\begin{array}{c}\text { Not } \\
\text { specified }\end{array}$ & $\begin{array}{l}\text { Gibbs and others } 1996 \\
\text { Branen and others } 2001 \\
\text { Watson } 2002\end{array}$ \\
\hline
\end{tabular}


Koyama and others 2003

GRAS No. 000468

Kroger and others 2006

E960

Stevia

EU Regulation No.

$4 \mathrm{mg} / \mathrm{kg} \quad$ Carakostas and others 2008

$1129 / 2011$

bw

EFSA 2010a

Lemus-Mondaca and others

2012 
Table 6-Stabilizers with use restrictions and their respective ADI quantities ( $\mathrm{mg} / \mathrm{kg} \mathrm{bw})$

\begin{tabular}{|c|c|c|c|c|}
\hline E number & Name & Legislation & ADI & References \\
\hline $\begin{array}{l}\mathrm{E} 400- \\
\mathrm{E} 404\end{array}$ & Alginates & $\begin{array}{c}\text { Code of Federal } \\
\text { Regulations } 21 \\
\text { Sec.184.1011 } \\
- \\
\text { EU Regulation No. } \\
\text { 1129/2011 }\end{array}$ & - & Bouyer and others 2012 \\
\hline E407 & Carrageenan & $\begin{array}{c}\text { Code of Federal } \\
\text { Regulations } 21 \\
\text { Sec.172.620 } \\
- \\
\text { EU Regulation No. } \\
\text { 1129/2011 } \\
\end{array}$ & - & $\begin{array}{c}\text { Tobacman } 2001 \\
\text { Weiner and others } 2007 \\
\text { Yang and others } 2012\end{array}$ \\
\hline $\mathrm{E} 440$ & Pectin & $\begin{array}{c}\text { Code of Federal } \\
\text { Regulations } 21 \\
\text { Sec.184.1588 } \\
- \\
\text { EU Regulation No. } \\
\text { 1129/2011 } \\
\end{array}$ & - & $\begin{array}{c}\text { Akhtar and others } 2002 \\
\text { Leroux } 2003\end{array}$ \\
\hline
\end{tabular}




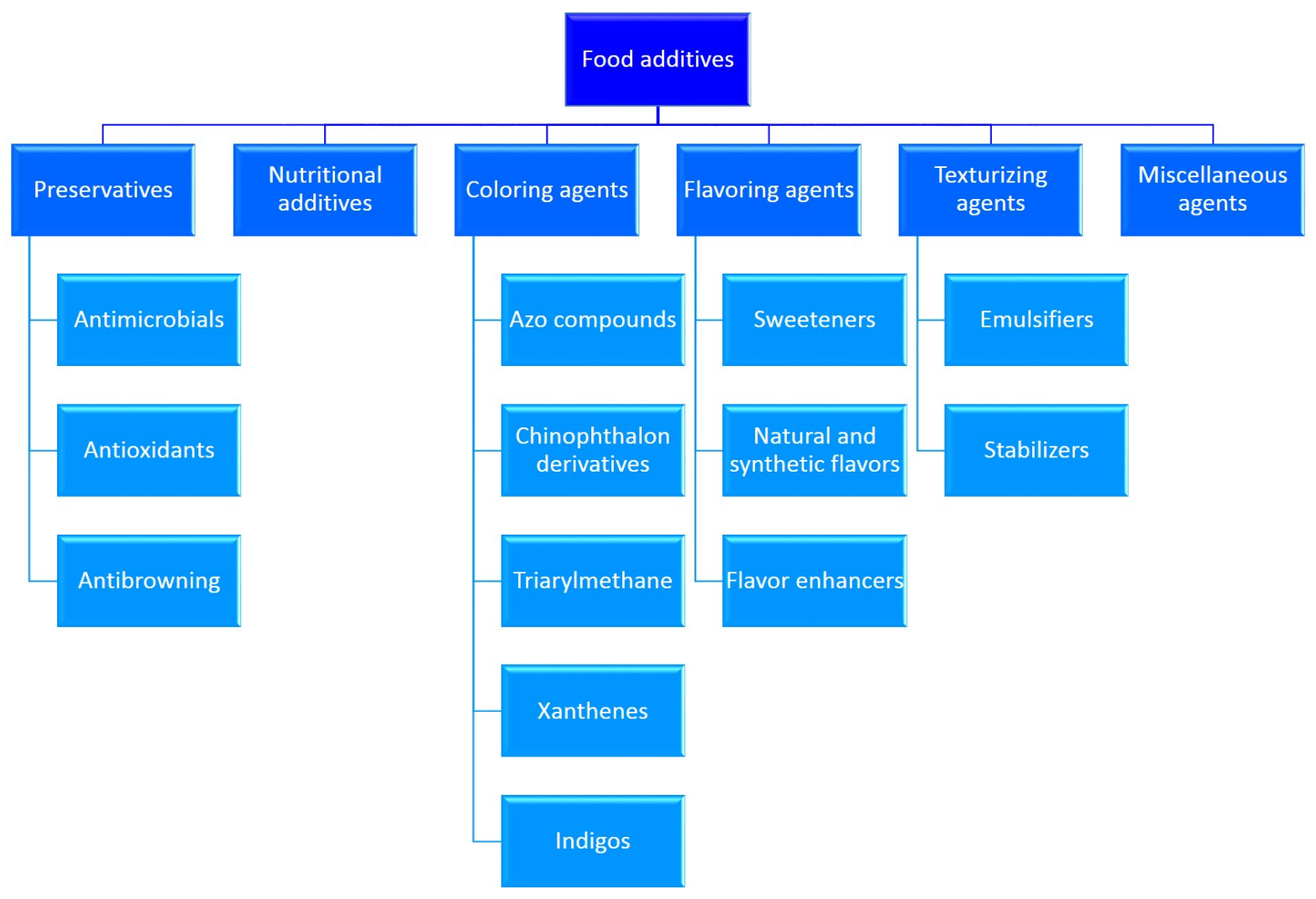

Figure 1-Groups and sub-groups of food additives. Adapted from Branen and others (2001), Watson (2002) and Sarikaya and others (2012). 